\title{
Wnt signaling and cancer
}

\author{
Paul Polakis ${ }^{1}$ \\ Department of Molecular Oncology, Genentech Inc., South San Francisco, California 94080 USA
}

The regulation of cell growth and survival can be subverted by a variety of genetic defects that alter transcriptional programs normally responsible for controlling cell number. High throughput analysis of these gene expression patterns should ultimately lead to the identification of minimal expression profiles that will serve as common denominators in assigning a cancer to a given category. In the course of defining the common denominators, though, we should not be too surprised to find that cancers within a single category may nevertheless exhibit seemingly disparate genetic defects. The wnt pathway has already provided an outstanding example of this. We now know of three regulatory genes in this pathway that are mutated in primary human cancers and several others that promote experimental cancers in rodents (Fig. 1). In all of these cases the common denominator is the activation of gene transcription by $\beta$-catenin. The resulting gene expression profile should provide us with a signature common to those cancers carrying defects in the wnt pathway. In this review, the wnt pathway will be covered from the perspective of cancer, with emphasis placed on molecular defects known to promote neoplastic transformation in humans and in animal models.

\section{The wnt signaling mechanism}

The model illustrated in Figure 2 is a proposed mechanism for wnt signaling and is based on the following literature. Signaling is initiated by the secreted wnt proteins, which bind to a class of seven-pass transmembrane receptors encoded by the frizzled genes (Bhanot et al. 1996; Yang-Snyder et al. 1996; He et al. 1997). Activation of the receptor leads to the phosphorylation of the dishevelled protein which, through its association with axin, prevents glycogen synthase kinase $3 \beta$ (GSK3 $\beta$ ) from phosphorylating critical substrates (Itoh et al. 1998; Kishida et al. 1999; Lee et al. 1999; Peters et al. 1999; Smalley et al. 1999/. In vertebrates, the inactivation of GSK3 $\beta$ might result from its interaction with Frat-1 (Thomas et al. 1999; Yost et al. 1998; Li et al. 1999a; Salic et al. 2000). The GSK3 $\beta$ substrates include the negative regulators axin and $\mathrm{APC}$, as well as $\beta$-catenin itself (Rubinfeld et al. 1996; Yost et al. 1996; Yamamoto et al. 1999). Unphosphorylated $\beta$-catenin escapes recognition by $\beta$-TRCP, a component of an E3 ubiquitin ligase, and translocates to the nucleus where it engages transcrip-

1E-MAIL ppolakis@gene.com; FAX (650) 225-1641. tion factors such as TCF and LEF (Behrens et al. 1996; Molenaar et al. 1996; Hart et al. 1999). Additional components in the pathway include casein kinases I and II, both of which have been proposed to phosphorylate dishevelled (Sakanaka et al. 1999; Willert et al. 1997; Peters et al. 1999). The serine/threonine phosphatase PP2A associates with axin and APC, although its functional role in the pathway remains obscure (Hsu et al. 1999; Seeling et al. 1999). Also obscure is the manner by which the wnt receptors communicate with dishevelled.

\section{Receptors, ligands, and related proteins}

The proto-oncogenic effects of wnt were discovered over 18 years ago inciting intense investigation into the role of wnt genes in human cancer (Nusse and Varmus 1982). The subsequent discovery of wingless, the fly homolog of wnt-1, paved the way for assembling a signaling pathway subsequently found to contain cancer causing genes (Cabrera et al. 1987; Rijsewijk et al. 1987). Although wnt was the prototypical oncogene in this pathway, no formal proof for its involvement in human cancer has ever been documented. There have been numerous reports on the overexpression, and sometimes underexpression, of wnt genes in human cancers, but mRNA expression levels are merely correlative. More compelling evidence, such as amplification, rearrangement, or mutation of genes encoding wnt ligands or receptors has not been forthcoming. In lieu of these sorts of findings, we are left to speculate on the consequences of epigenetic events implicating these genes in human cancer. In doing so we can use animal and cell culture models to guide our interpretation.

The wnt ligands, of which there are at least 16 members in vertebrates, are secreted glycoproteins that can be loosely categorized according to their ability to promote neoplastic transformation (for review, see Wodarz and Nusse 1998). For example, the activation of wnt-1, wnt3 , or wnt-10b by retroviral insertion in the mammary gland will promote tumor formation in mice (Lee et al. 1995; Nusse and Varmus 1982; Roelink et al. 1990). Oncogenic potential can also be assessed in cultured mammalian cells, such as C57MG and CH310T1/2, where expression of the proto-oncogenic wnts results in morphological transformation (Bradbury et al. 1994; Wong et al. 1994). These cells are transformed by wnt-1, wnt-2, wnt3a but not by wnt-4, wnt-5a, and wnt- 6 . The transforming wnt genes also promote the accumulation of $\beta$-catenin in some cultured mammalian cells (Shimizu et 


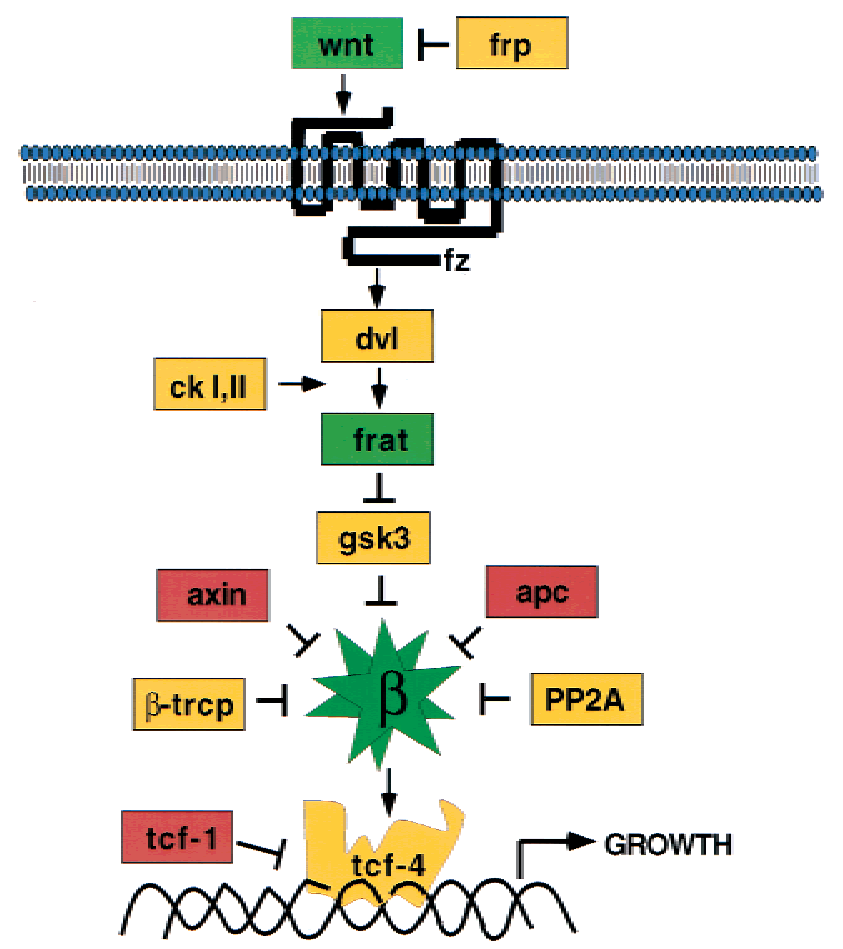

Figure 1. Oncogenes and tumor suppressors in the wnt signaling pathway. Lines ending with arrows or bars indicate activating or inhibitory effects, respectively. Green and red indicate proto-oncogenic and tumor suppressive activity, respectively, in human cancer or transgenic animals. Definition of the genes and the basis for their activities are described in the text.

al. 1997). Some aspects of the wnt cancer pathway are also recapitulated in Xenopus development, where injection of transforming wnts into early embryos results in duplication of the dorsal axis (Wodarz and Nusse 1998). A caveat here is that the lack of specific receptors for certain wnts might also explain their inactivity in some of these assays (He et al. 1997). Nevertheless, identifying those wnts capable of neoplastic transformation will aid the interpretation of epigenetic evidence implicating wnts in cancer. For example, expression of the wnt-16 gene is activated by the $\mathrm{E} 2 \mathrm{~A}-\mathrm{Pbx} 1$ fusion product in acute lymphoblastoid leukemia (McWhirter et al. 1999), but the oncogenic potential of wnt-16 is unknown.

As might be expected from the plethora of wnt genes, there are also numerous wnt receptors. At least 11 vertebrate frizzled genes have been identified, but how they differ in function and ligand specificity is far from clear. The analysis of mere binding specificity may not be sufficient to sort out the appropriate combinations of functional receptor-ligand interactions. Wnt-3a and wnt-5a both bind to Human frizzled 1 (Hfzl), yet only wnt-3a mediates TCF-dependent transcription (Gazit et al. 1999). This suggests that the activation of TCF/LEF-dependent transcription is a good correlate to neoplastic transformation. Implementation of this assay, along with a second assay involving the translocation of PKC to the cell membrane, resulted in the categorization of murine wnt receptors into two exclusive groups (Sheldahl et al. 1999|. Human FzE3 fell into the TCF/LEF activation group, consistent with previous work showing that its overexpression resulted in nuclear localization of $\beta$-catenin (Tanaka et al. 1998). This receptor was also expressed in numerous human esophageal cancers, but not in matched normal tissue (Tanaka et al. 1998).

In addition to the frizzled receptors, there exists a family of secreted proteins bearing homology to the extracellular cysteine-rich domain of frizzled. The so-called secreted frizzled-related proteins (sFRP) bind to the wnt ligands, thereby exerting antagonistic activity when overexpressed in wnt signaling assays (Leyns et al. 1997; Wang et al. 1997). The vertebrate sFRPs, like the frizzled proteins, exhibit functional specificity with respect to the various wnts. In Xenopus assays, the prototypical frizzled related protein frzb, now known as sFRP-3, inhibited wnt-1 and wnt-8, but not wnt-5a (Leyns et al. 1997; Lin et al. 1997; Wang et al. 1997). Assays in mammalian cells showed that FrzA, now termed sFRP-1, inhibited wnt-1-induced accumulation of $\beta$-catenin (Dennis et al. 1999; Melkonyan et al. 1997). Again, binding specificity may not relate to functional specificity, as wnt-5a associated with sFRP-3 but was unable to inhibit its activity (Lin et al. 1997). Even the significance of specific functional interactions might be suspect based on recent titration experiments with purified soluble sFRP1. At low concentrations sFRP-1 enhanced signaling activity by soluble wingless protein, whereas at higher concentrations it was inhibitory (Uren et al. 2000). The authors proposed high and low states of binding affinity that involved the carboxy-terminal heparin binding domain and the amino-terminal cysteine-rich domain of sFRP-1, respectively. Binding to the cysteine-rich domain might confer inhibition while binding to the carboxy-terminal region could facilitate presentation of active ligand to receptor. The potential for some sFRPs to activate wnt signaling is consistent with a previous study in which sFRP-2, then known as SARP-1, increased the intracellular concentration of $\beta$-catenin and conferred anti-apoptotic properties to cultured MCF-7 cells (Melkonyan et al. 1997). Functional studies are further complicated by the binding of a sFRP to the putative human receptor frizzled-6, underscoring additional possible modes of regulation (Bafico et al. 1999). The sFRPs have not been directly linked to cancer, but one could speculate that the anti-apoptotic activity observed with the SARP-1 could contribute to tumor progression. Alternatively, the identification of sFRP-2 as a target of the hedgehog signaling pathway might be relevant to human basal cell cancers (Lee et al. 2000). Additional structurally distinct secreted inhibitors of wnt signaling include the recently discovered dickopft-1 and wif-1 proteins (Fedi et al. 1999; Glinka et al. 1998; Hsieh et al. 1999).

\section{GSK3 $\beta$}

The serine/threonine kinase GSK3 $\beta$ binds to and phosphorylates several proteins in the wnt pathway and is instrumental to the down regulation of $\beta$-catenin (Dominguez et al. 1995; He et al. 1995; Hedgepeth et al. 1999b; Ikeda et al. 1998; Itoh et al. 1998; Li et al. 1999a; Nakamura et al. 1998b; Rubinfeld et al. 1996; Yamamoto 
Wnt signaling and cancer
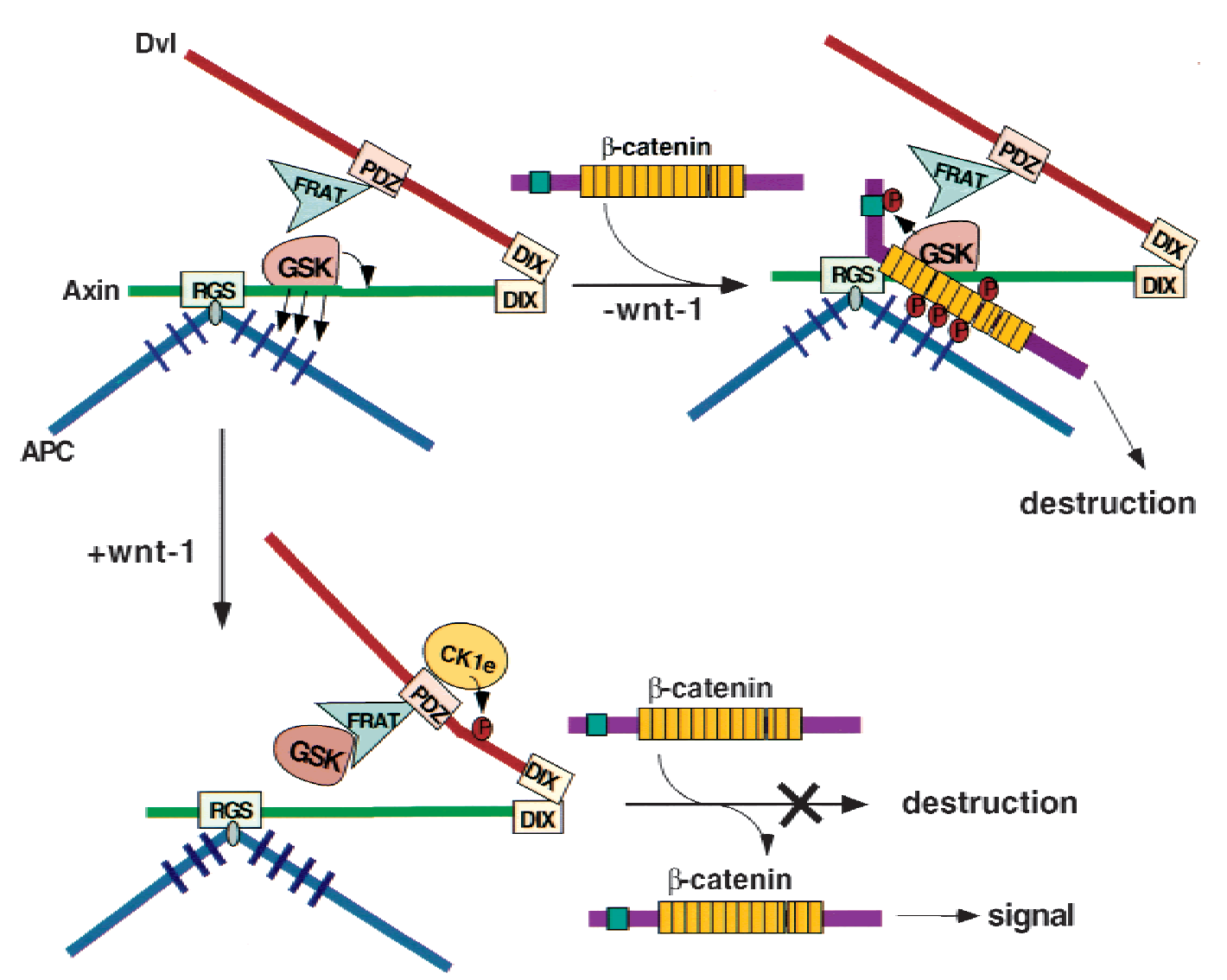

Figure 2. Proposed mechanism for the transmission of wnt signals. In the absence of wnt -wnt) GSK3 $\beta$ phosphorylates APC and axin, increasing their binding affinities for $\beta$-catenin, which too is phosphorylated by GSK3 $\beta$, marking it for destruction. In the presence of wnt (+wnt) FRAT prevents GSK3 $\beta$ from phosphorylating its substrates, and $\beta$-catenin is stabilized. Casein kinase $1 \epsilon(\mathrm{CK} 1 \epsilon)$ binds to and phosphorylates dishevelled (dvl) modulating the FRAT1/GSK3 $\beta$ interaction. RGS, PDZ, and DIX are protein interaction domains.

et al. 1999; Yost et al. 1996). As a negative regulator of wnt signaling, GSK3 $\beta$ would qualify as a potential tumor suppressor. However, mutations or deletions in the gene coding for GSK3 $\beta$ were not been detect ed in a survey of colorectal tumors (Sparks et al. 1998). Perhaps GSK3 $\beta$ can compensate for the loss of GSK3 $\beta$ and the biallelic inactivation of both these genes is unlikely in tumor progression. Alternatively, the utilization of GSK3 $\beta$ by pathways independent of wnt could make its overall ablation incompatible with cell viability. Nevertheless, inactivation of GSK3 $\beta$ can still be achieved by a means other than genetic ablation and can occur in a manner that uniquely affects wnt signaling. This mode of inactivation involves the association of GSK3 $\beta$ with Frat-1. Frat-1 was identified by insertional mutagenesis in a screen for genes that enhanced the progression of transplanted T-cell lymphomas in mice (Jonkers et al. 1997). Subsequent transgenic expression of Frat-1 alone did not induce spontaneous lymphomas, but greatly enhanced lymphomagenesis initiated either by leukemia virus $\mathrm{M}$ MuLV or expression of the Pim1 oncogene (Jonkers et al. 1999). A connection to GSK3 $\beta$ was realized by the discovery of the Frat-1 Xenopus homolog GBP, a GSK3 $\beta$ binding protein inhibitory to wnt signaling when ex- pressed in Xenopus embryos (Yost et al. 1998). Frat-1 is also antagonistic to wnt signaling in mammalian cells, presumably because it competes with axin for binding to GSK3 $\beta$ (Li et al. 1999a; Thomas et al. 1999). GBP also inhibited the phosphorylation and degradation of $\beta$-catenin in vitro when added to Xenopus extracts (Salic et al. 2000). Although Frat-1 contributes to cancer progression in a transgenic mouse model, its contribution to human cancer has not been documented.

\section{Dishevelled}

The genetic analysis of dishevelled in developmental systems has defined it as a positive mediator of wnt signaling positioned downstream of the receptor and upstream of $\beta$-catenin (Noordermeer et al. 1994). Overexpression or constitutive activation of dishevelled would be expected to promote neoplastic transformation, but its involvement in human cancers has not been reported. This might reflect the dual function of dishevelled, one that transduces wnt signals for the stabilization of $\beta$-catenin and a second that relays signals for the activation of jun kinases (Li et al. 1999b; Moriguchi et al. 1999|. Although these two functions are housed in physi- 
cally separable regions of the protein, dysregulation of one function, without impacting the other, could place severe constraints on selection for potential oncogenic mutations. A possible connection of dishevelled to cancer is through casein kinase II, which binds to and phosphorylates dishevelled and also promotes the formation of lymphomas when expressed in transgenic mice (Seldin and Leder 1995; Song et al. 2000; Willert et al. 1997).

\section{$\beta$-catenin}

Mutations in the $\beta$-catenin gene (CTNNb1) affecting the amino-terminal region of the protein make it refractory to regulation by APC (Morin et al. 1997; Rubinfeld et al. 1997). These mutations affect specific serine and threonine residues, and amino acids adjacent to them, that are essential for the targeted degradation of $\beta$-catenin (for review, see Polakis 1999). The mutations abrogate the phosphorylation dependent interaction of $\beta$-catenin with $\beta$-TRCP, a component of an E3 ubiquitin ligase that makes direct contact with amino terminal sequence in $\beta$-catenin (Hart et al. 1999). This regulatory sequence in $\beta$-catenin is mutated in a wide variety of human cancers as well as in chemically and genetically induced animal tumors. Importantly, $\beta$-catenin mutations in tumors are exclusive to those that inactivate APC. This is particularly apparent in colorectal cancer where the vast major- ity of these tumors contain APC mutations and the overall frequency of $\beta$-catenin mutations is quite low (Samowitz et al. 1999; Sparks et al. 1998; Kitaeva et al. 1997) (Table 1). When colorectal tumors lacking APC mutations were analyzed separately, the likelihood of finding a CTNNb1 mutation was greatly increased (Iwao et al. 1998; Sparks et al. 1998). The exclusivity of CTNNb1 and APC mutations in colorectal cancer was also evident from the analysis of replication error-positive tumors identified by microsatellite instability. Both the hereditary and sporadic forms of replication errorpositive colorectal cancers had a relatively high frequency of $\beta$-catenin mutations, whereas APC mutations were relatively rare (Mirabelli-Primdahl et al. 1999; Miyaki et al. 1999) (Table 1). Interestingly, this correlation between microsatellite instability and CTNNb1 mutations was not apparent in endometrial cancers (Mirabelli-Primdahl et al. 1999).

Aggressive fibromatosis, otherwise known as desmoid tumor, is a locally invasive fibrocytic growth that occurs with increased incidence in patients with familial adenomatous polyposis coli (FAP). FAP individuals carry APC mutations in their germline and present with multiple intestinal adenomas at an early age. Desmoids also occur sporadically and, with the exception of colorectal cancer, represent a rare example of biallelic inactivation of APC in individuals without a pre-existing germline mutation in APC (Alman et al. 1997). Not surprisingly, mutations

Table 1. Beta-catenin mutations in human cancers

\begin{tabular}{|c|c|c|c|c|c|c|c|c|c|c|c|c|c|c|c|c|c|c|c|c|c|c|c|c|}
\hline tissue & freq. & $\mathbf{S 2 9}$ & $Y 30$ & L31 & D32 & S33 & G34 & 135 & H36 & $\mathbf{S 3 7}$ & G38 & A39 & $\mathrm{T} 40$ & $T 41$ & T42 & A43 & P44: & 545 & $5 \mathrm{~L} 46$ & 547 & G48 & K49 & \begin{tabular}{|l|l|l}
$\Delta$ & 1 \\
\end{tabular} & reference \\
\hline & & & & & & & & & & & & & & & & & & & & & & & & \\
\hline colorectal & $9 / 202$ & & & & & & 1 & & & & & & & 3 & & & & 5 & & & & & 0 & Samowitz 1999 \\
\hline colorectal & $2 / 92$ & & & & & & & & & & & & & 1 & & & & 1 & & & & & & \begin{tabular}{|l|l|} 
Kitaeva & 1997 \\
\end{tabular} \\
\hline colorectal-w/o APC mutation & $7 / 58$ & & & & & & & & & & & & & & & & & & & & & & 7 & Iwao 1998 \\
\hline colorectal-w/o APC mutation & $13 / 27$ & & & & & 2 & 1 & & & & & & & 3 & & & & 5 & & & & & 1 & Sparks 1998 \\
\hline colorectal HNPCC & $12 / 28$ & & & & 2 & & 2 & & & 1 & & & & 2 & & & & 5 & & & & & & Miyaki 1999 \\
\hline colorectal w/ MSI & $13 / 53$ & & & & & & & & & & & & & & & & & \begin{tabular}{c|c}
6 & $-10-10$
\end{tabular} & & & & & & Mirabelli-primdahl 1999 \\
\hline colorectal w/o MSI & $0 / 27$ & & & & & & & & & & & & & & & & & & & & & & & Mirabelli-primdahl 1999 \\
\hline desmoid, sporadic & $1 / 1$ & & & & & & & & & & & & & 1 & & & & & & & & & 0 & Shitoh 1999 \\
\hline desmoid, sporadic & $22 / 42$ & & & & & & & & & & & & & 10 & & & & 12 & & & & & & Tejpar 1999 \\
\hline endometrial $\mathrm{w} / \mathrm{MSI}$ & $3 / 9$ & & & & 2 & 1 & & & & & & & & & & & & & & & & & & Mirabelli-primdahl 1999 \\
\hline endometrial w/o MSI & $10 / 20$ & & & & 3 & 1 & 2 & & & 3 & & & & 1 & & & & & & & & & & Mirabelli-primdahl 1999 \\
\hline gastric, Intestinal-type & $7 / 26$ & 2 & & & 5 & & & & & & & & & & & & & & & & & & & Park 1999 \\
\hline gastric, diffuse-type & $0 / 17$ & & & & & & & & & & & & & & & & & & & & & & & Park 1999 \\
\hline hepatocellular w/HCV & $9 / 22$ & & & & 3 & 1 & & & & 3 & & & & 1 & & & & 2 & & & & & & Huang 1999 \\
\hline hepatocellular & $12 / 35$ & & & & 1 & 1 & 2 & 1 & 1 & & & & 1 & 2 & & & & 2 & & 1 & & & 2 & Van Nhieu 1999 \\
\hline hepatocellular & $6 / 26$ & & & & 2 & & 1 & & & 1 & & & & & & & & 1 & & & & & 1 & de la Coste 1998 \\
\hline hepatocellular & $14 / 75$ & & & & 5 & 1 & 1 & & & & & & & 1 & & & & 4 & & & & & 2 & Miyoshi 1998 \\
\hline hepatocellular & $21 / 119$ & & & & 3 & 3 & 1 & 1 & & 2 & & & & 4 & & & & 8 & & & & & 2 & Legoix 1999 \\
\hline hepatoblastoma, sporadic & $8 / 9$ & & & & & & 2 & & & 1 & & & & & & & & 1 & & & & & 4 & Jeng 2000 \\
\hline hepatoblastoma, sporadic & $27 / 52$ & & & & 2 & & 3 & & & 1 & & & & 5 & & & & & & & & & 16 & Koch 1999 \\
\hline hepatoblastoma & $12 / 18$ & & & & 2 & & 1 & & & & & & & 1 & & & & 1 & & & & & 7 & Wei 2000 \\
\hline kidney, Wilm's tumor & $6 / 40$ & & & & & & & & & & & & & 1 & & & & 2 & & & & & 3 & Koesters 1999 \\
\hline medulloblastoma, sporaic & $3 / 67$ & & & & & 2 & & & & 1 & & & & & & & & & & & & & & Zurawel 1998 \\
\hline melanoma & $1 / 65$ & & & & & & & & & & & & & & & & & 1 & & & & & & Garcia-Rostan 1999 \\
\hline ovarian, endometriod & $7 / 13$ & & & & 3 & 1 & & & & 2 & & & & 1 & & & & & & & & & 0 & Gamallo 1999 \\
\hline ovarian, endometriod & $3 / 11$ & & & & & & & & & 2 & & & & 1 & & & & & & & & & & Palacios 1998 \\
\hline ovarian, endometriod & $10 / 63$ & & & & & 2 & 2 & & & 6 & & & & & & & & & & & & & & Wright 1999 \\
\hline pancreatic tumors & $0 / 111$ & & & & & & & & & & & & & & & & & & & & & & & Gerdes 1999 \\
\hline pilomatricoma & $12 / 16$ & & & & 2 & 4 & 3 & & & 2 & & & & 1 & & & & & & & & & & Chan 1999 \\
\hline prostate cancer & $5 / 104$ & & & & 1 & 2 & & & & & & & & 1 & & & & 1 & & & & & & Voeller 1998 \\
\hline thyroid, anaplastic & $19 / 31$ & & & & & 1 & & & 1 & 3 & 1 & & 8 & 2 & 1 & 1 & 4 & 2 & 1 & 2 & & 9 & 0 & Garcia-rostan 1999 \\
\hline uterine endometrium & $10 / 76$ & & & & & 1 & & & & 2 & & & & 4 & & & & \begin{tabular}{l|l}
3 & 1
\end{tabular} & & & & & & Fukuchi 1998 \\
\hline
\end{tabular}

Amino acids affected by mutations in CTNNb1 gene are indicated for sequence located between serine-29 (S29) and lysine-49 (K49). The overall frequency (freq.) of mutations in each tumor type is represented as the number of tumors with mutations/total number of tumors analyzed. The amino acid affected by the mutation and the number of mutations at each position are listed across columns. Interstitial deletions affecting one or more amino acids in the sequence are indicated as $\Delta$. In some cases, more than one mutation was found in a single tumor and therefore the sum of all mutations exceeds the number of tumors with mutations. 
in $C T N N b 1$ have also been detected in sporadic desmoid tumors (Shitoh et al. 1999; Tejpar et al. 1999). The $\beta$-catenin mutations were found in over half of the 42 desmoids analyzed, while inactivating mutations in APC were detected in nine and, again, there was no overlap between APC and $\beta$-catenin mutations (Tejpar et al. 1999). The $\beta$-catenin mutations were all of the missense variety and were confined to codons 41 and 45 . Some of the desmoids lacked mutations in either $\beta$-catenin or APC, but all displayed increased expression of $\beta$-catenin, implying that yet unidentified defects in $\beta$-catenin regulation exist in some of these tumors.

There appears to be a low probability of accruing biallelic inactivating mutations in APC in most sporadic cancers, despite increased cancer incidence at numerous extracolonic sites in FAP patients. This suggests that the stabilization of $\beta$-catenin can promote cancer in many tissue types, but the biallelic inactivation of APC is an unlikely means to this end. Components in the wnt pathway other than APC, such as $\beta$-catenin, might make easier targets for oncogenic mutations. Indeed, several mutations in $C T N N b 1$ were recently identified in gastric cancers, which occur with increased incidence in FAP patients (Park et al. 1999). In this study, 27\% of intestinal type gastric cancers harbored mutations in $\beta$-catenin. Hepatoblastoma also occurs with increased incidence in FAP individuals (Hughes and Michels 1992; Giardiello et al. 1996; Cetta et al. 1997), but biallelic inactivation of APC is uncommon in the sporadic forms of these tumors. In three separate studies, mutations in $\beta$-catenin were identified at high frequency in hepatoblastoma, while no APC mutations were found (Koch et al. 1999; Jeng et al. 2000; Wei et al. 2000). Hepatoblastoma is also associated with Beckwidth-Wiedemann syndrome (BWS), however, a direct link between wnt signaling and the genetic defects underlying BWS are unlikely as a tumor from one of these patients also contained a somatic mutation in $\beta$-catenin (Wei et al. 2000). By contrast, a subset of patients with Turcot's syndrome harbor germline mutations in APC and are at increased risk of medulloblastoma (Hamilton et al. 1995; Lasser et al. 1994). Although inactivating mutations in APC have not been detected in the sporadic forms of medulloblastoma, CTNNb1 mutations were found in a small percentage (Zurawel et al. 1998).

Hepatocellular carcinoma (HCC) has become one of the most common tumors harboring mutations in the wnt pathway. Based on five separate studies, the frequency of $C T N N b 1$ mutations in hepatocellular carcinoma (HCC) was $\sim 20 \%$ overall and perhaps higher still for HCCs associated with hepatitis C virus (de La Coste et al. 1998; Miyoshi et al. 1998; Huang et al. 1999; Legoix et al. 1999; Van Nhieu et al. 1999) (Table 1). Preliminary data indicated a poorer prognosis associated with nuclear accumulation of $\beta$-catenin in HCC and histological data indicated enhanced nuclear staining in the invasive and intravascular compartments of the tumors (Huang et al. 1999; Van Nhieu et al. 1999). In one of these studies an inverse correlation between $\beta$-catenin mutations and loss of heterozygosity in the genome was noted (Legoix et al. 1999). This suggests that chromosomal instability and mutations in CTNNb1 represent alternative modes of tumor progression in HCC.

It is noteworthy that c-myc and cyclin D genes are amplified in a subset of HCCs and both these genes are downstream targets of $\beta$-catenin (He et al. 1998; Nishida et al. 1994; Peng et al. 1993; Shtutman et al. 1999; Tetsu and McCormick 1999). It would be of interest to determine whether any overlap exists between their amplification and CTNNb1mutations in HCC. Animal models of HCC have provided some clues toward understanding the relationship between these genes in cancer. HCCs induced by transgenic expression of SV40 T antigen in murine liver did not contain mutations in CTNNb1 (Umeda 2000). As T antigen activates cyclin D kinase by sequestration of $\mathrm{Rb}$, the activation of the cyclin $\mathrm{D}$ gene by mutant $\beta$-catenin may no longer be required. By contrast, activating mutations in $C T N N b 1$ were identified in half of the HCCs generated by transgenic expression of c-myc in murine liver (de La Coste et al. 1998). This animal model suggests that $\beta$-catenin mutations occur as a second "hit" in HCC tumor progression in cooperation with a distinct cancer pathway initiated by c-myc. That CTNNb1 mutations can occur subsequent to other oncogenic defects is also evident from their occurrence in Wilm's tumor. Mutations in $\beta$-catenin were detected in $15 \%$ of these pediatric kidney cancers and in two of these cases they were concomitant with mutations in the Wilm's tumor gene WT1 (Koesters et al. 1999). One of these cases was associated with Denys-Drash syndrome, a familial disorder attributable to germline mutations in WT1.

It makes sense that extracolonic tumors associated with FAP, such as desmoids, medulloblastoma, and HCC, would contain CTNNb1 mutations in their sporadic forms. Thyroid cancers also occur with increased incidence in FAP and, not surprisingly, a high frequency of $C T N N b 1$ mutations was recently reported for anaplastic thyroid cancers (Cetta et al. 2000; Garcia-Rostan et al. 1999|. Although many of these mutations affected amino acids known to influence the regulation of $\beta$-catenin, many of them affected residues for which the consequence of their mutation is unknown (Garcia-Rostan et al. 1999). In particular, the substitution K49R was detected nine times. This mutation was frequently detected in the context of independent CTNNb1 mutations in the same thyroid tumor, and up to four independent $C T N N b 1$ mutations were found in some tumors. The occurrence of multiple independent CTNNb1 mutations was also noted in some HCCs and might reflect the multifocal origin of some cancers (Huang et al. 1999; Legoix et al. 1999; Van Nhieu et al. 1999). In one HCC study, examination of different tumor areas from the same patient revealed distinct $C T T N b 1$ mutations in two independent cases (Huang et al. 1999).

Some cancers, such as endometrial ovarian tumors, do not occur with increased incidence in patients with FAP, yet they contain activating mutations in CTNNb1 $(\mathrm{Pa}-$ lacios and Gamallo 1998; Gamallo et al. 1999; Wright et al. 1999). Perhaps inactivation of the remaining wild- 
type $A P C$ allele in FAP individuals is unlikely in this tissue, or the expression of an alternative APC gene compensates for its loss. The CTNNb1 mutations associated with ovarian cancer appeared to be confined to the endometrioid subtype. In this tissue, cancers with activated $\beta$-catenin signaling were reported to be less aggressive than their nonactivated counterparts. In one report, a more favorable prognosis was associated with cancers exhibiting enhanced nuclear staining of $\beta$-catenin and another indicated higher frequency of CTNNb1 mutations in lower grade tumors (Palacios and Gamallo 1998; Wright et al. 1999). A similar inverse correlation between tumor grade and occurrence of CTNNb1 mutations was also reported for uterine endometrial cancers (Fukuchi et al. 1998). The overlap between mutations in CTNNb1 and other gene defects in ovarian cancers has not been explored in detail, although one study noted coexisting mutations in the PTEN tumor suppressor and CTNNb1 in endometrioid tumors (Wright et al. 1999).

Additional types of cancers with CTNNb1 mutations, albeit at low frequency, include melanoma and prostate. Although only one of sixty-five melanomas contained detectable mutations, nuclear localization of the protein was seen in one-third (Rimm et al. 1999). Thus, additional mechanisms for $\beta$-catenin activation likely occur in these tumors. Possibly the highest percentage of CTNNb1 mutations occurs in a common skin tumor known as pilomatricomas (Chan et al. 1999). That these tumors might contain CTNNb1 mutations was surmised from the genesis of similar tumors in transgenic mice expressing mutant $\beta$-catenin in the skin (Gat et al. 1998). The tumors appeared to originate from the hair follicle, which is consistent with the lack of hair in mice homozygous for mutations in LEF, a transcription factor responsive to $\beta$-catenin (van Genderen et al. 1994).

\section{Axin}

Axin was originally identified as an inhibitor of wnt signaling in Xenopus embryos and was subsequently shown to bind directly to APC, $\beta$-catenin, GSK3 $\beta$ and dishevelled (for review, see Peifer and Polakis 2000). A plethora of in vitro and in vivo studies in Xenopus, Drosophila, and cultured mammalian cells has demonstrated that axin is central to the down regulation of $\beta$-catenin (Zeng et al. 1997; Behrens et al. 1998; Hart et al. 1998; Ikeda et al. 1998; Nakamura et al. 1998a; Sakanaka et al. 1998; Fagotto et al. 1999; Hedgepeth et al. 1999a; Li et al. 1999a; Willert et al. 1999a; Farr et al. 2000). It is not entirely clear how axin functions, but it has been proposed to facilitate the phosphorylation of $\beta$-catenin and APC by GSK3 $\beta$ (Hart et al. 1998; Ikeda et al. 1998). Thus axin would be viewed as a tumor suppressor based on its ability to downregulate signaling, and this has now been verified by documentation of its biallelic inactivation in human hepatocellular cancers and cell lines (Satoh et al. 2000). Importantly, these mutations were identified in those HCCs that lacked activating mutations in CTNNb1. All of the mutations were predicted to truncate the axin protein in a manner that eliminated the $\beta$-catenin binding sites. Axin, which should now be regarded as a tumor suppressor, constitutes the third genetic defect in the wnt pathway that contributes to human cancer. There also exists a close homolog of axin termed conductin, which exhibits of all the binding and regulatory functions of axin (Behrens et al. 1998). That this apparent redundancy did not suppress axin mutations in HCC suggests conductin is either not functionally equivalent to axin or not expressed at levels sufficient to compensate for its loss in HCCs.

\section{PP2A}

The dependence upon serine/threonine kinases for the regulation of $\beta$-catenin implies that phosphatases are also involved. Indeed, the rapid dephosphorylation of the axin protein is a consequence of wnt signaling and has been proposed to both destabilize axin and reduce its affinity for $\beta$-catenin (Willert et al. 1999b; Yamamoto et al. 1999). Although axin binds directly to the PP2A catalytic subunit, the phosphatase affecting axin in response to wnt signaling has not been identified (Hsu et al. 1999). If $\mathrm{PP} 2 \mathrm{~A}$ is this phosphatase, it would be viewed as protooncogenic because it downregulates the tumor suppressor axin. On the contrary, expression of the PP2A regulatory subunit B56 in human colon cancer cells results in the downregulation of $\beta$-catenin, consistent with a tumor suppressive function in the wnt pathway (Seeling et al. 1999). Moreover, the beta isoform of the PP2A A subunit is deleted in some human colon tumors, again implying tumor suppression (Wang et al. 1998). Also, disruption of twins, a Drosophila gene coding for a PP2A subunit, complemented the overexpression and underexpression of the $\beta$-catenin homolog armadillo, in a manner consistent with negative regulation of wnt signaling (Greaves et al. 1999). By all accounts, PP2A plays a role in wnt signaling, but its potential role as proto-oncogene or tumor suppressor might be dependent upon the precise nature of the defect.

\section{APC}

Genetic analysis of FAP families led to the identification of the $A P C$ gene, and subsequent studies demonstrating an interaction with $\beta$-catenin placed it tentatively in the wnt pathway (Groden et al. 1991; Kinzler et al. 1991; Munemitsu et al. 1995; Rubinfeld et al. 1993; Su et al. 1993). Experiments in Drosophila ultimately revealed that genetic ablation of APC indeed resulted in upregulation of $\beta$-catenin signaling (Ahmed et al. 1998). In some systems, such as Xenopus and Caenorhabditis elegans, a positive role for APC in the wnt pathway has been proposed, but the former study suffers from potential overexpression artifacts and the latter from a lack of relatedness to the vertebrate APC protein (Rocheleau et al. 1997; Vleminckx et al. 1997). In any case, APC is a tumor suppressor in human cancers and its mutation relates strongly to the regulation of $\beta$-catenin. The spectrum of APC mutations, which typically truncate the protein, suggest selection against $\beta$-catenin regulatory domains, 
albeit not necessarily against $\beta$-catenin binding (for review, see Polakis 1999). The selective pressure might be directed against the presence of Axin binding sites, of which there are three, dispersed across the central region of the APC protein (Behrens et al. 1998). The presence of axin binding sites are critical to APC in the regulation of $\beta$-catenin levels and signaling in cultured cells (Kawahara et al. 2000). Moreover, mice lacking wild-type APC but expressing a truncated mutant APC retaining a single axin binding site are viable and do not develop intestinal neoplasia (Smits et al. 1999). This has not been the case for mice with more extensive truncations in APC (Oshima et al. 1995a; Su et al. 1992). Also, milder forms of colorectal polyposis, as well as familial infiltrative fibromatosis (desmoid tumors), have been associated with germline mutations in the $3^{\prime}$ region of the APC open reading frame. These mutations predict truncated proteins that retain only one or two of the three axin binding sites in APC (Walon et al. 1997; Kartheuser et al. 1999; Scott et al. 1996; van der Luijt et al. 1996). A recent study has also demonstrated that the expression of just the central region of APC, which contains all of the axin and $\beta$-catenin binding sites, was sufficient to elicit cellular growth suppression (Shih et al. 2000). This effect is consistent with previous work showing that a like fragment of APC was sufficient to downregulate $\beta$-catenin levels in cancer cells (Munemitsu et al. 1995).

Although both copies of the APC gene are typically inactivated in colorectal cancers, it remains possible that a mutant truncated APC could contribute to cancer progression. This was tested by transgenic expression of two different APC mutants in a wild-type intestinal background (Oshima et al. 1995b). This did not result in cancer-prone mice, despite high levels of expression of mutant proteins and, therefore, argues against a dominant negative effect by these particular mutants. However, it does not rule out an additive contribution to tumor progression by mutant APC protein in a background lacking wildtype APC. In fact, genetic evidence argues in favor of selection for a somewhat specific mutant APC protein. The mutation cluster region (MCR) in APC, roughly defined by codons 1250-1500, is not only consistent with selection against specific sequence, but also retention of an APC molecule that extends into the MCR (Fig. 3.). A correlation between the presence of a germline mutation in the MCR and the severity of polyposis has been noted (Ficari et al. 2000; Nagase et al. 1992; Wu et al. 1998). The enhanced severity of polyposis suggests there should

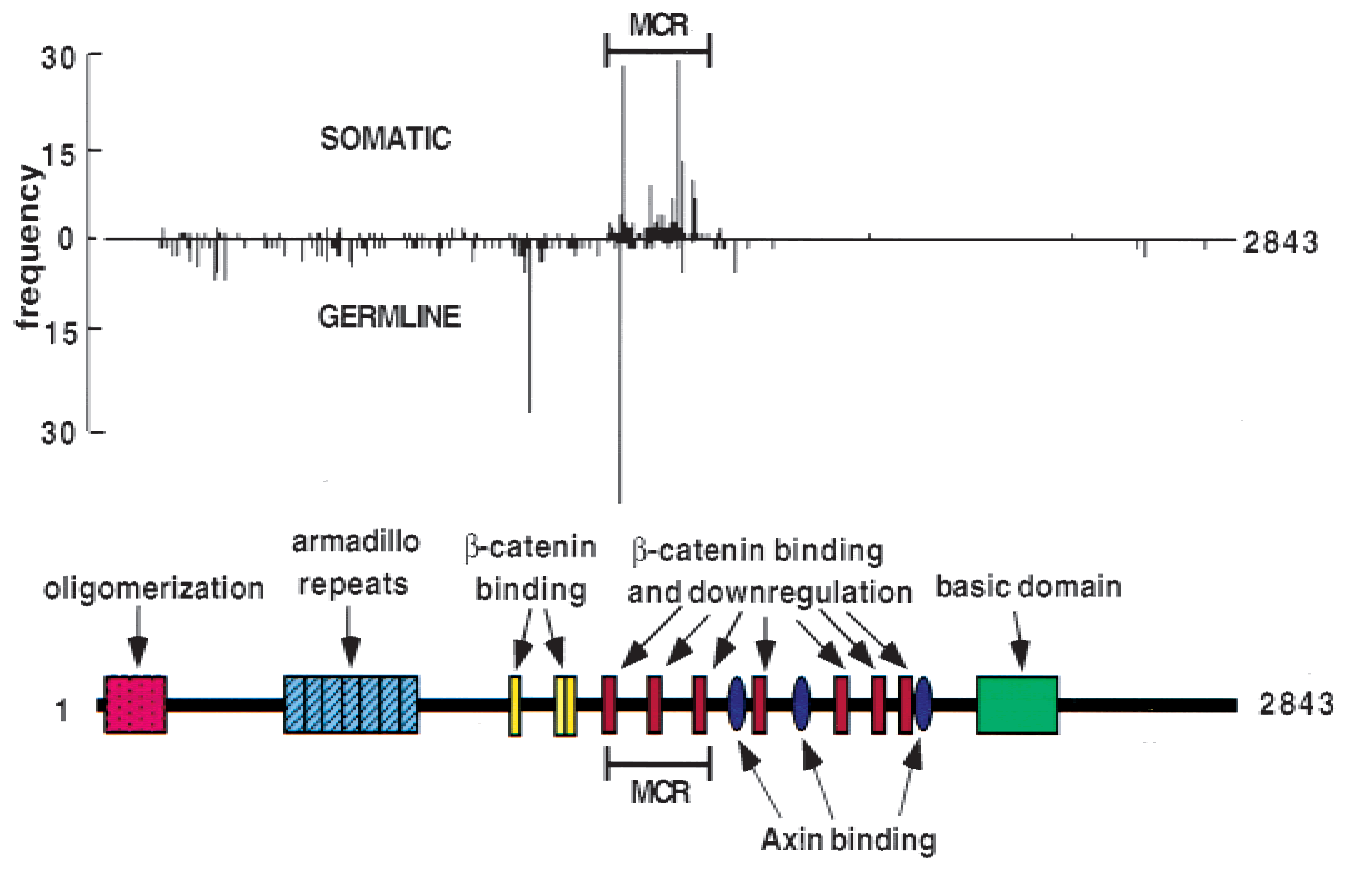

(FIRST HIT) GERMLINE MUTATION

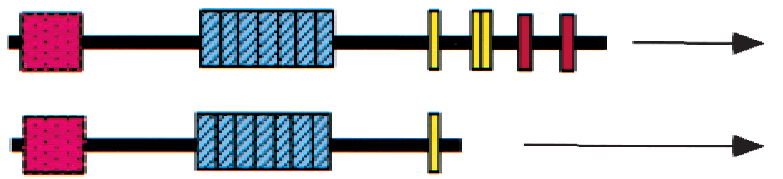

(SECOND HIT) SOMATIC MUTATION

LOSS OF WT ALLELE (LOH)

TRUCATION IN MCR

Figure 3. Mutations in APC. A compilation of germline and somatic mutations in APC illustrates selection for mutations in the mutation cluster region (MCR). MCR mutations result in truncated proteins retaining $\beta$-catenin binding but not regulatory activity. Somatic MCR mutations are more frequently selected for in FAP patients with germline mutations outside of the MCR. 
also be selective pressure for somatic mutations in the MCR, which indeed appears to be the case (Miyoshi et al. 1992). Selective pressure for an MCR mutant has also been proposed based on the occurrence of somatic mutations in the MCR relative to the position of the germline mutation in FAP (Lamlum et al. 1999). Tumors from FAP patients with a germline MCR mutation exhibited frequent inactivation of the remaining APC allele by $\mathrm{LOH}$, while those without a germline MCR mutation had frequent somatic mutations in the MCR (Fig. 3). Therefore, a germline mutation in the MCR could relieve the constraint for a subsequent somatic MCR mutation, thereby increasing the likelihood of polyposis. This implies that a truncated MCR APC mutant has an interfering or gain of function property that enhances tumor progression beyond simple loss of APC function. An interfering function would probably not involve interaction with wild-type APC, as recently suggested, because the MCR mutant is still selected for in the absence of a wild-type APC gene copy (Dihlmann et al. 1999). Finally, some of the germline mutations in APC do not disrupt the open reading frame yet correlate with increased risk of colorectal cancer (Frayling et al. 1998; Gryfe et al. 1999; Laken et al. 1997). These mutations have been proposed to increase the occurrence of subsequent truncating mutations by enhancing the mutational susceptibility of the affected nucleotide tract.

\section{Transcription factors}

Prior to discussing the potential role for LEF/TCF transcription factors in cancer, it is important to outline the mechanism by which they have been proposed to operate. Although LEF/TCFs bind directly to DNA through their HMG domains, they are incapable of independently activating gene transcription (Eastman and Grosschedl 1999; Roose and Clevers 1999). This has best been illustrated for LEF, which through its binding to the cofactor ALY, makes indirect contacts with a second transcription factor AML (Bruhn et al. 1997). The TCFs do not contain the ALY binding site, but like LEF they cannot activate test genes comprised of multimerized TCF/LEF binding sites and a minimal promotor sequence. However, these reporter genes are activated on coexpression of TCF with $\beta$-catenin, suggesting that $\beta$-catenin supplies additional cofactors required for transcriptional activation (Molenaar et al. 1996). This activity was localized to the carboxy-terminal region of the Drosophila $\beta$-catenin armadillo, which when fused directly to TCF resulted in $\beta$-catenin independent transcriptional activation (van de Wetering et al. 1997).

The simple interpretation is that the TCF/LEF- $\beta$ catenin complex comprises a bipartite positive acting transcription factor in the wnt pathway. This interpretation agrees well with developmental studies in which the manipulation of LEF/TCF function results in phenotypes consistent with the genetic manipulation of wnt/ $\beta$-catenin signaling (Behrens et al. 1996; Brunner et al. 1997; Huber et al. 1996; van de Wetering et al. 1997). For example, a zygotic homozygous null mutation in Dro- sophila LEF results in a loss of naked cuticle in the larval epidermis, a phenotype typical of loss of function wingless mutations (Brunner et al. 1997). Moreover, the formation of excess naked cuticle by ectopic expression of armadillo in wild-type embryos does not occur in the LEF null mutants. Exactly how $\beta$-catenin contributes to transcriptional activation is unclear, but might involve additional proteins that bridge the TCF/ $\beta$-catenin complex to the basal transcriptional machinery. The bridging function might be fulfilled by Pontin 52, a TATA-binding protein that was reported to bind to $\beta$-catenin (Bauer et al. 1998). Also, a mutant form of $\beta$-catenin incapable of binding LEF squelched LEF-dependent reporter gene activation, presumably by titration of an essential cofactor (Prieve and Waterman 1999). Finally, the carboxyterminal region of armadillo binds to the Zinc finger protein teashirt, a homeotic gene essential for a subset of wingless signaling outputs in Drosophila (Gallet et al. 1999).

The simple model of positive transcriptional activation by the TCF- $\beta$-catenin complex is not in accord with all experiments. Mutation of the TCF/LEF binding sites in the promotors of the wingless responsive gene ultrabithorax and the Wnt-responsive Xenopus gene Siamois enhanced their activities under conditions where the wingless/ $\beta$-catenin signal input was weak (Brannon et al. 1999; Riese et al. 1997). The mammalian cyclin D gene was recently identified as a wnt target and, again, mutation of the corresponding TCF binding sites enhanced its basal activity (Tetsu and McCormick 1999). These results suggest TCF represses transcription of its target genes in unstimulated cells and the binding of $\beta$-catenin promotes derepression. Derepression cannot fully account for signaling activity, however, as mutations in the TCF binding sites compromise target gene activation under conditions of active wnt signaling (Brannon et al. 1999; Riese et al. 1997). Repression of gene expression by TCF is consistent with its direct physical interaction with at least three different gene products, the Groucho/TLE and CtBP corepressors, and the CREB binding protein CBP (Brannon et al. 1999; Cavallo et al. 1998; Levanon et al. 1998; Roose et al. 1998; Waltzer and Bienz 1998).

The groucho/TLE proteins bind to the central region of TCF/LEF at a site distinct from that of $\beta$-catenin binding and inhibit gene activation of TCF target genes (Levanon et al. 1998; Roose et al. 1998). By contrast, CtBP binds to two independent sites in the carboxy-terminal region of Xtcf-3, which when mutated abrogated the repressor function of this region of Xtcf-3 (Brannon et al. 1999). The binding sites for CtBP are not present in LEF, which might explain the ability of LEF, but not Xtcf-3, to induce axis duplication in Xenopus embryos. Finally, the Drosophila CREB binding protein CBP was reported to bind to the HMG domain of dTCF (Waltzer and Bienz 1998). Loss-of-function CBP mutants displayed some features of wingless over expression and also suppressed phenotypes resulting from loss of the $\beta$-catenin homolog armadillo. The genetics imply suppression of wingless by CBP, which is somewhat paradoxical when consider- 
ing the role of CBP acetyltransferase activity in chromatin remodeling and gene activation. However, it was shown that CBP acetylates a lysine proximal to the armadillo binding site in TCF, thereby reducing its affinity for armadillo. Repression of $\beta$-catenin/TCF signaling by CBP does not occur in all settings, though, as two recent studies demonstrated activation of Xenopus TCF target genes by CBP (Hecht et al. 2000; Takemaru and Moon 2000). CBP directly associated with carboxy-terminal sequence in $\beta$-catenin and overexpression of E1A, which also directly binds CBP, reduced $\beta$-catenin dependent transactivation.

Does the activation of TCF/LEF target genes by $\beta$-catenin cause cancer? Good evidence to this effect was provided by the expression of a chimeric protein consisting of the LEF DNA binding sequence fused to the transcriptional activation domain of either VP16 or the estrogen receptor (Aoki et al. 1999). Expression of these constructs in chicken embryo fibroblasts resulted in their neoplastic transformation. The proliferative potential of TCF was also apparent from the phenotype resulting from homozygous disruption of TCF-4 in the germline of mice. These animals were incapable of maintaining a proliferative stem cell compartment in the small intestine and died shortly after birth (Korinek et al. 1998). Whether the TCF/LEF genes are directly activated by mutations in cancer is unclear, but mutations in TCF-4 have been detected in a subset of colorectal tumors (Duval et al. 1999). The mutations all occur as single base deletions in an (A)9 nucleotide repeat within the $3^{\prime}$ coding region of the gene. These deletions generate frame shifts predicted to effect the proportion of the long and short forms of TCF that normally result from alternative mRNA splicing. The mutations were also found in cancer cell lines, all of which possessed mutations in either APC or $\beta$-catenin. This indicates that the TCF mutations do not substitute for APC/ $\beta$-catenin mutations but could act in an additive manner.

An additional mechanism by which TCFs could contribute to cancer was gleaned from the phenotype of mice homozygous for mutations in TCF-1 (Roose et al. 1999|. Fifteen percent of these animals developed adenomatous intestinal polyps by one year of age, implicating TCF-1 as a tumor suppressor. The major isoforms of TCF-1 do not contain a $\beta$-catenin binding site and could therefore act in a dominant negative manner in wnt signaling. Crossing TCF-1 null mice with cancer-prone ApcMin/+ mice resulted in offspring with ten times the number of intestinal polyps relative to ApcMin/+ littermates. This experimental model suggests that the genetic ablation of TCF-1 could modify, or even independently contribute to cancer progression in humans. Additional potential mechanisms for cancer would include the inactivation of corepressors such as CtBP and TLE/ groucho.

\section{Cross talk}

Defects leading to activation of the wnt pathway could also occur in signaling systems that are seemingly unre- lated to wnt signaling. One potential mode of cross talk includes the kinase TAK1, which can substitute for MAPK kinase kinase in the yeast pheromone pathway. TAK1 (TGF- $\beta$ activated kinase) is activated by TGF- $\beta$ in mammalian cells and has also been implicated in interleukin-1 activation of NFкB (Ninomiya-Tsuji et al. 1999; Yamaguchi et al. 1995). In c. elegans, the TAK1 homolog MOM-4 negatively regulates the TCF homolog POP-1 by activating another kinase LIT-1, which then phosphorylates POP-1 (Meneghini et al. 1999; Shin et al. 1999). LIT-1 is thought to gain access to POP-1 through its direct binding to the $\beta$-catenin homolog WRM-1 (Shin et al. 1999|. Parallel interactions have been demonstrated for the mammalian counterparts of these proteins where the phosphorylation of TCF, by the LIT-1 homolog NLK, reduces its DNA binding affinity (Ishitani et al. 1999). Thus a MAPK-like signaling system might downregulate the wnt-1 pathway. A second opportunity for cross talk with wnt signaling was realized by a physical interaction between the $\beta$-catenin-TCF complex and SMAD4, a mediator of TGF- $\beta$ signaling (Nishita et al. 2000). This interaction was proposed to be synergistic with respect to the activation of the Xenopus wnt target gene twin. How this relates to cancer is somewhat puzzling when considering that TGF- $\beta$ signaling is typically compromised by genetic and epigenetic defects during tumor progression.

An additional mode of cross regulation was recently revealed by the discovery that retinoids inhibit $\beta$-catenin dependent gene transcription (Easwaran et al. 1999). $\beta$-catenin associated with a retinoic acid receptor (RAR) and cooperated with retinoids to enhance activation of a retinoic acid responsive promotor. Moreover, the identification of RAR- $\gamma$ as a target of wnt signaling in Xenopus also points to an interaction between these signaling systems (McGrew et al. 1999). Signaling by $\beta$-catenin was also reported to be repressed by expression of sox 3 and sox17 transcription factors, which associated directly with $\beta$-catenin (Zorn et al. 1999). Although inhibition of $\beta$-catenin signaling was clearly demonstrated, it is also possible that $\beta$-catenin drives gene activation independent of LEF/TCF, through its association with the sox proteins. Finally, the activation of the WISP genes by $\beta$-catenin is highly dependent upon the presence of a CREB binding site in the WISP promotor (Xu et al. 2000). This implies that cAMP-dependent protein kinase A feeds into wnt signaling and might cooperate with the activation of some wnt target genes. The binding of $\mathrm{CBP}$ to $\beta$-catenin is particularly relevant with respect to this proposal (Hecht et al. 2000; Takemaru and Moon 2000).

\section{Conclusion}

It is apparent that wnt signaling causes cancer and that tumor promotion by this pathway can proceed through a number of different genetic defects. Additional mechanisms by which defects in the regulation of wnt signaling contribute to tumor progression probably remain 
undiscovered. The manifestation of cancer by aberrant wnt signaling most likely results from inappropriate gene activation mediated by stabilized $\beta$-catenin. Target genes need not contain TCF/LEF binding sites in their promotors, though, as new potential modes of gene activation by $\beta$-catenin are becoming apparent. Several target genes of $\beta$-catenin signaling have now been identified and some of their functions are consistent with control of cellular growth, differentiation, and survival. For an excellent summary of wnt target genes, and a wealth of information on wnt signaling in general, I refer the reader to the Wnt Home Page posted by the Nusse lab (http://www.stanford.edu/rnusse/wntwindow.html).

\section{References}

Ahmed, Y., Hayashi, S., Levine, A., and Wieschaus, E. 1998. Regulation of armadillo by a Drosophila APC inhibits neuronal apoptosis during retinal development. Cell 93: 11711182.

Alman, B.A., Li, C., Pajerski, M.E., Diaz-Cano, S., and Wolfe, H.J. 1997. Increased beta-catenin protein and somatic APC mutations in sporadic aggressive fibromatoses (desmoid tumors). Am. J. Pathol. 151: 329-334.

Aoki, M., Hecht, A., Kruse, U., Kemler, R., and Vogt, P.K. 1999. Nuclear endpoint of Wnt signaling: Neoplastic transformation induced by transactivating lymphoid-enhancing factor 1. Proc. Natl. Acad. Sci. 96: 139-144.

Bafico, A., Gazit, A., Pramila, T., Finch, P.W., Yaniv, A., and Aaronson, S.A. 1999. Interaction of frizzled related protein (FRP) with Wnt ligands and the frizzled receptor suggests alternative mechanisms for FRP inhibition of Wnt signaling. J. Biol. Chem. 274: 16180-16187.

Bauer, A., Huber, O. and Kemler, R. 1998. Pontin52, an interaction partner of beta-catenin, binds to the TATA box binding protein. Proc. Natl. Acad. Sci. 95: 14787-14792.

Behrens, J., von Kries, J.P., Kuhl, M., Bruhn, L., Wedlich, D., Grosschedl, R., and Birchmeier, W. 1996. Functional interaction of beta-catenin with the transcription factor LEF-1. Nature 382: 638-642.

Behrens, J., Jerchow, B.A., Wurtele, M., Grimm, J., Asbrand, C., Wirtz, R., Kuhl, M., Wedlich, D., and Birchmeier, W. 1998. Functional interaction of an axin homolog, conductin, with $\beta$-catenin, APC, and GSK3 $\beta$. Science 280: 596-599.

Bhanot, P., Brink, M., Samos, C.H., Hseih, J.C., Wang, W., Macke, J.P., Andew, D., Nathans, J., and Nusse, R. 1996. A new member of the frizzled family from Drosophila functions as a wingless receptor. Nature 282: 225-230.

Bradbury, J.M., Niemeyer, C.C., Dale, T.C., and Edwards, P.A. 1994. Alterations of the growth characteristics of the fibroblast cell line $\mathrm{C} 3 \mathrm{H} 10 \mathrm{~T} 1 / 2$ by members of the Wnt gene family. Oncogene 9: 2597-2603.

Brannon, M., Brown, J.D., Bates, R., Kimelman, D., and Moon, R.T. 1999. XCtBP is a XTcf-3 co-repressor with roles throughout Xenopus development. Development 126: 31593170.

Bruhn, L., Munnerlyn, A., and Grosschedl, R. 1997. ALY, a context-dependent coactivator of LEF-1 and AML-1, is required for TCR $\alpha$ enhancer function. Genes \& Dev. 11: 640-653.

Brunner, E., Peter, O., Schweizer, L., and Basler, K. 1997. pangolin encodes a Lef- 1 homologue that acts downstream of Armadillo to transduce the Wingless signal in Drosophila. $\mathrm{Na}$ ture 385: 829-833.
Cabrera, C.V., Alonso, M.C., Johnston, P., Phillips, R.G., and Lawrence, P.A. 1987. Phenocopies induced with antisense RNA identify the wingless gene. Cell 50: 659-663.

Cavallo, R.A., Cox, R.T., Moline, M.M., Roose, J., Polevoy, G.A., Clevers, H., Peifer, M., and Bejsovec, A. 1998. Drosophila Tcf and Groucho interact to repress Wingless signalling activity. Nature 395: 604-608.

Cetta, F., Montalto, G., and Petracci, M. 1997. Hepatoblastoma and APC gene mutation in familial adenomatous polyposis. Gut 41: 417.

Cetta, F., Montalto, G., Gori, M., Curia, M.C., Cama, A., and Olschwang, S. 2000. Germline mutations of the APC gene in patients with familial adenomatous polyposis-associated thyroid carcinoma: Results from a European cooperative study. J. Clin. Endocrinol. Metab. 85: 286-292.

Chan, E.F., Gat, U., McNiff, J.M., and Fuchs, E. 1999. A common human skin tumour is caused by activating mutations in $\beta$-catenin. Nat. Genet. 21: 410-413.

de La Coste, A., Romagnolo, B., Billuart, P., Renard, C.A., Buendia, M.A., Soubrane, O., Fabre, M., Chelly, J., Beldjord, C., Kahn, A., et al. 1998. Somatic mutations of the beta-catenin gene are frequent in mouse and human hepatocellular carcinomas. Proc. Nat1. Acad. Sci. 95: 8847-8851.

Dennis, S., Aikawa, M., Szeto, W., d'Amore, P.A., and Papkoff, J. 1999. A secreted frizzled related protein, FrzA, selectively associates with Wnt-1 protein and regulates wnt-1 signaling. J. Cell. Sci. 112: 3815-3820.

Dihlmann, S., Gebert, J., Siermann, A., Herfarth, C., and von Knebel Doeberitz, M. 1999. Dominant negative effect of the APC1309 mutation: A possible explanation for genotypephenotype correlations in familial adenomatous polyposis. Cancer Res. 59: 1857-1860.

Dominguez, I., Itoh, K., and Sokol, S.Y. 1995. Role of glycogen synthase kinase 3 beta as a negative regulator of dorsoventral axis formation in Xenopus embryos. Proc. Natl. Acad. Sci. 92: 8498-8502.

Duval, A., Gayet, J., Zhou, X.P., Iacopetta, B., Thomas, G, and Hamelin, R. 1999. Frequent frameshift mutations of the TCF-4 gene in colorectal cancers with microsatellite instability. Cancer Res. 59: 4213-4215.

Eastman, Q. and Grosschedl, R. 1999. Regulation of LEF-1/TCF transcription factors by Wnt and other signals. Curr. Opin. Cell. Biol. 11: 233-240.

Easwaran, V., Pishvaian, M., Salimuddin, and Byers, S. 1999. Cross-regulation of beta-catenin-LEF/TCF and retinoid signaling pathways. Curr. Biol. 9: 1415-1418.

Fagotto, F., Jho, E., Zeng, L., Kurth, T., Joos, T., Kaufmann, C., and Costantini, F. 1999. Domains of axin involved in protein-protein interactions, Wnt pathway inhibition, and intracellular localization. J. Cell Biol. 145: 741-756.

Farr, G.H., 3rd, Ferkey, D.M., Yost, C., Pierce, S.B., Weaver, C., and Kimelman, D. 2000. Interaction among GSK-3, GBP, axin, and APC in Xenopus axis specification. J. Cell Biol. 148: 691-702.

Fedi, P., Bafico, A., Nieto Soria, A., Burgess, W.H., Miki, T., Bottaro, D.P., Kraus, M.H., and Aaronson, S.A. 1999. Isolation and biochemical characterization of the human Dkk-1 homologue, a novel inhibitor of mammalian Wnt signaling. J. Biol. Chem. 274: 19465-19472.

Ficari, F., Cama, A., Valanzano, R., Curia, M.C., Palmirotta, R., Aceto, G., Esposito, D.L., Crognale, S., Lombardi, A., Messerini, L., et al. 2000. APC gene mutations and colorectal adenomatosis in familial adenomatous polyposis. Br. J. Cancer 82: 348-353.

Frayling, I.M., Beck, N.E., Ilyas, M., Dove-Edwin, I., Goodman, P., Pack, K., Bell, J.A., Williams, C.B., Hodgson, S.V., Thom- 
as, H.J., et al. 1998. The APC variants I1307K and E1317Q are associated with colorectal tumors, but not always with a family history. Proc. Natl. Acad. Sci. 95: 10722-10727.

Fukuchi, T., Sakamoto, M., Tsuda, H., Maruyama, K., Nozawa, S., and Hirohashi, S. 1998. Beta-catenin mutation in carcinoma of the uterine endometrium. Cancer Res. 58: 35263528.

Gallet, A., Angelats, C., Erkner, A., Charroux, B., Fasano, L., and Kerridge, S. 1999. The C-terminal domain of armadillo binds to hypophosphorylated teashirt to modulate wingless signalling in Drosophila. EMBO J. 18: 2208-2217.

Gamallo, C., Palacios, J., Moreno, G., Calvo de Mora, J., Suarez, A., and Armas, A. 1999. beta-catenin expression pattern in stage I and II ovarian carcinomas: Relationship with betacatenin gene mutations, clinicopathological features, and clinical outcome. Am. J. Pathol. 155: 527-536.

Garcia-Rostan, G., Tallini, G., Herrero, A., D'Aquila, T.G. Carcangiu, M.L., and Rimm, D.L. 1999. Frequent mutation and nuclear localization of beta-catenin in anaplastic thyroid carcinoma. Cancer Res. 59: 1811-1815.

Gat, U., DasGupta, R., Degenstein, L., and Fuchs, E. 1998. De novo hair follicle morphogenesis and hair tumors in mice expressing a truncated beta-catenin in skin. Cell 95: 605614.

Gazit, A., Yaniv, A., Bafico, A., Pramila, T., Igarashi, M., Kitajewski, J., and Aaronson, S.A. 1999. Human frizzled 1 interacts with transforming Wnts to transduce a TCF dependent transcriptional response. Oncogene 18: 5959-5966.

Gerdes B, Ramaswamy, A., Simon, B., Pietsch, T., Bastian, D., Kersting, M., Moll, R., and Bartsch, D. 1999. Analysis of beta-catenin gene mutations in pancreatic tumors. Digestion 60: 544-548.

Giardiello, F.M., Petersen, G.M., Brensinger, J.D., Luce, M.C., Cayouette, M.C., Bacon, J., Booker, S.V., and Hamilton, S.R. 1996. Hepatoblastoma and APC gene mutation in familial adenomatous polyposis. Gut 39: 867-869.

Glinka, A., Wu, W., Delius, H., Monaghan, A.P., Blumenstock, C., and Niehrs, C. 1998. Dickkopf-1 is a member of a new family of secreted proteins and functions in head induction. Nature 391: 357-362.

Greaves, S., Sanson, B., White, P., and Vincent, J.P. 1999. A screen for identifying genes interacting with armadillo, the Drosophila homolog of beta-catenin. Genetics 153: 17531766.

Groden, J., Thliveris, A., Samowitz, W., Carlson, M., Gelbert, L., Albertsen, H., Joslyn, G., Stevens, J., Spirio, L., Robertson, M.L., et al. 1991. Identification and characterization of the familial adenomatous polyposis gene. Cell 66: 589-600.

Gryfe, R., Di Nicola, N., Lal, G., Gallinger, S., and Redston, M. 1999. Inherited colorectal polyposis and cancer risk of the APC I1307K polymorphism. Am. J. Hum. Genet. 64: 378-384.

Hamada, F., Tomoyasu, Y., Takatsu, Y., Nakamura, M., Nagai, S., Suzuki, A., Fujita, F., Shibuya, H., Toyoshima, K., Ueno, N., et al. 1999. Negative regulation of Wingless signaling by D-axin, a Drosophila homolog of axin. Science 283: 17391742.

Hamilton, S.R., Liu, B., Parsons, R.E., Papadopoulos, N., Jen, J., Powell, S.M., Krush, A.J., Berk, T., Cohen, Z., Tetu, B., et al. 1995. The molecular basis of Turcot's syndrome. N. Engl. J. Med. 332: 839-847.

Hart, M., Concordet, J.P., Lassot, I., Albert, I., del los Santos, R., Durand, H., Perret, C., Rubinfeld, B., Margottin, F., Benarous, R., et al. 1999. The F-box protein beta-TrCP associates with phosphorylated beta-catenin and regulates its activity in the cell. Curr. Biol. 9: 207-210.

Hart, M.J., de los Santos, R., Albert, I.N., Rubinfeld, B., and
Polakis, P. 1998. Downregulation of beta-catenin by human Axin and its association with the APC tumor suppressor, beta-catenin and GSK3 beta. Curr. Biol. 8: 573-581.

He, T.C., Sparks, A.B., Rago, C., Hermeking, H., Zawel, L., da Costa, L.T., Morin, P.J., Vogelstein, B., and Kinzler, K.W. 1998. Identification of c-MYC as a target of the APC pathway. Science 281: 1509-1512.

He, X., Saint-Jeannet, J.P., Woodgett, J.R., Varmus, H.E., and Dawid, I.B. 1995. Glycogen synthase kinase-3 and dorsoventral patterning in Xenopus embryos. Nature 374: 617-623.

He, X., Saint-Jeannet, J.P., Wang, Y., Nathans, J., Dawid, I., and Varmus, H. 1997. A member of the Frizzled protein family mediating axis induction by Wnt-5A. Science 275: 16521654.

Hecht, A., Vleminckx, K., Stemmler, M.P., van Roy, F., and Kemler, R. 2000. The p300/CBP acetyltransferases function as transcriptional coactivators of beta-catenin in vertebrates. EMBO J. 19: 1839-1850.

Hedgepeth, C.M., Deardorff, M.A., and Klein, P.S 1999a. Xenopus axin interacts with glycogen synthase kinase- 3 beta and is expressed in the anterior midbrain. Mech. Dev. 80: 147151.

Hedgepeth, C.M., Deardorff, M.A., Rankin, K., and Klein, P.S. $1999 \mathrm{~b}$. Regulation of glycogen synthase kinase $3 \beta$ and downstream Wnt signaling by axin. Mol. Cell Biol. 19: 7147-7157.

Hsieh, J.C., Kodjabachian, L., Rebbert, M.L., Rattner, A., Smallwood, P.M., Samos, C.H., Nusse, R., Dawid, I.B., and Nathans, J. 1999. A new secreted protein that binds to Wnt proteins and inhibits their activities. Nature 398: 431-436.

Hsu, W., Zeng, L., and Costantini, F. 1999. Identification of a domain of Axin that binds to the serine/threonine protein phosphatase 2A and a self-binding domain. J. Biol. Chem. 274: 3439-3445.

Huang, H., Fujii, H., Sankila, A., Mahler-Araujo, B.M., Matsuda, M., Cathomas, G., and Ohgaki, H. 1999. Beta-catenin mutations are frequent in human hepatocellular carcinomas associated with hepatitis C virus infection. Am. I. Pathol. 155: 1795-1801.

Huber, O., Korn, R., McLaughlin, J., Ohsugi, M., Herrmann, B.G., and Kemler, R. 1996. Nuclear localization of betacatenin by interaction with transcription factor LEF-1. Mech. Dev. 59: 3-10.

Hughes, L.J. and Michels, V.V. 1992. Risk of hepatoblastoma in familial adenomatous polyposis. Am. I. Med. Genet. 43: 1023-1025.

Ikeda, S., Kishida, S., Yamamoto, H., Murai, H., Koyama, S., and Kikuchi, A. 1998. Axin, a negative regulator of the Wnt signaling pathway, forms a complex with GSK-3 $\beta$ and $\beta$-catenin and promotes GSK-3 $\beta$-dependent phosphorylation of $\beta$-catenin. EMBO J. 17: 1371-1384.

Ishitani, T., Ninomiya-Tsuji, J., Nagai, S., Nishita, M., Meneghini, M., Barker, N., Waterman, M., Bowerman, B., Clevers, H., Shibuya, H., et al. 1999. The TAK1-NLK-MAPKrelated pathway antagonizes signalling between betacatenin and transcription factor TCF. Nature 399: 798-802.

Itoh, K., Krupnik, V.E., and Sokol, S.Y. 1998. Axis determination in Xenopus involves biochemical interactions of axin, glycogen synthase kinase 3 and beta-catenin. Curr. Biol. 8: $591-594$.

Iwao, K., Nakamori, S., Kameyama, M., Imaoka, S., Kinoshita, M., Fukui, T., Ishiguro, S., Nakamura, Y., and Miyoshi, Y. 1998. Activation of the beta-catenin gene by interstitial deletions involving exon 3 in primary colorectal carcinomas without adenomatous polyposis coli mutations. Cancer Res. 58: 1021-1026.

Jeng, Y., Wu, M., Mao, T., Chang, M., and Hsu, H. 2000. Somatic 
mutations of beta-catenin play a crucial role in the tumorigenesis of sporadic hepatoblastoma. Cancer Lett. 152: 45-51.

Jonkers, J., Korswagen, H.C., Acton, D., Breuer, M., and Berns, A. 1997. Activation of a novel proto-oncogene, Frat1, contributes to progression of mouse T-cell lymphomas. EMBO J. 16: 441-450.

Jonkers, J., Weening, J.J., van der Valk, M., Bobeldijk, R., and Berns, A. 1999. Overexpression of Frat1 in transgenic mice leads to glomerulosclerosis and nephrotic syndrome, and provides direct evidence for the involvement of Frat 1 in lymphoma progression. Oncogene 18: 5982-5990.

Kartheuser, A., Walon, C., West, S., Breukel, C., Detry, R., Gribomont, A.C., Hamzehloei, T., Hoang, P., Maiter, D., Pringot, J., et al 1999. Familial adenomatous polyposis associated with multiple adrenal adenomas in a patient with a rare 3' APC mutation. J. Med. Genet. 36: 65-67.

Kawahara, K., Morishita, T., Nakamura, T., Hamada, F., Toyoshima, K., and Akiyama, T. 2000. Down-regulation of beta-catenin by the colorectal tumor suppressor APC requires association with Axin and beta-catenin. J. Biol. Chem. 275: 8369-8374.

Kinzler, K.W., Nilbert, M.C., Su, L.-K., Vogelstein, B., Bryan, T.M., Levy, D.B, Smith, K.J., Preisinger, A.C., Hedge, P., McKechnie, D., et al. 1991. Identification of FAP locus genes from chromosome 5q21. Science 253: 661-664.

Kishida, S., Yamamoto, H., Hino, S., Ikeda, S., Kishida, M., and Kikuchi, A. 1999. DIX domains of Dvl and axin are necessary for protein interactions and their ability to regulate betacatenin stability. Mol. Cell. Biol. 19: 4414-4422.

Kitaeva, M.N., Grogan, L., Williams, J.P., Dimond, E., Nakahara, K., Hausner, P., DeNobile, J.W., Soballe, P.W., and Kirsch, I.R. 1997. Mutations in beta-catenin are uncommon in colorectal cancer occurring in occasional replication error-positive tumors. Cancer Res. 57: 4478-4481.

Koch, A., Denkhaus, D., Albrecht, S., Leuschner, I., von Schweinitz, D., and Pietsch, T. 1999. Childhood hepatoblastomas frequently carry a mutated degradation targeting box of the beta-catenin gene. Cancer Res. 59: 269-273.

Koesters, R., Ridder, R., Kopp-Schneider, A., Betts, D., Adams, V., Niggli, F., Briner, J., and von Knebel Doeberitz, M. 1999. Mutational activation of the beta-catenin proto-oncogene is a common event in the development of Wilms' tumors. Cancer Res. 59: 3880-3882.

Korinek, V., Barker, N., Moerer, P., van Donselaar, E., Huls, G., Peters, P.J., and Clevers, H. 1998. Depletion of epithelial stem-cell compartments in the small intestine of mice lacking Tcf-4. Nat. Genet. 19: 379-383.

Laken, S.J., Petersen, G.M., Gruber, S.B., Oddoux, C., Ostrer, H., Giardiello, F.M., Hamilton, S.R., Hampel, H., Markowitz, A., Klimstra, D., et al. 1997. Familial colorectal cancer in Ashkenazim due to a hypermutable tract in APC. Nat. Genet. 17: 79-83.

Lamlum, H., Ilyas, M., Rowan, A., Clark, S., Johnson, V., Bell, J., Frayling, I., Efstathiou, J., Pack, K., Payne, S., et al. 1999. The type of somatic mutation at APC in familial adenomatous polyposis is determined by the site of the germline mutation: A new facet to Knudson's 'two-hit' hypothesis. Nat. Med. 5: 1071-1075.

Lasser, D., DeVivo, D., Garvin, J., and Wilhelmsen, K. 1994. Turcot's syndrome: Evidence for linkage to the adenomatous polyposis coli (APC) locus. Neurology 44: 1083-1086.

Lee, C.S., Buttitta, L.A., May, N.R., Kispert, A., and Fan, C.M. 2000. SHH-N upregulates Sfrp2 to mediate its competitive interaction with WNT1 and WNT4 in the somitic mesoderm. Development 127: 109-118.

Lee, F.S., Lane, T.F., Kuo, A., Shackleford, G.M., and Leder, P.
1995. Insertional mutagenesis identifies a member of the Wnt gene family as a candidate oncogene in the mammary epithelium of int-2/Fgf-3 transgenic mice. Proc. Natl. Acad. Sci. 92: 2268-2272.

Lee, J.S., Ishimoto, A., and Yanagawa, S. 1999. Characterization of mouse dishevelled (Dvl) proteins in Wnt/Wingless signaling pathway. J. Biol. Chem. 274: 21464-21470.

Legoix, P., Bluteau, O., Bayer, J., Perret, C., Balabaud, C., Belghiti, J., Franco, D., Thomas, G., Laurent-Puig, P., and Zucman-Rossi, J. 1999. Beta-catenin mutations in hepatocellular carcinoma correlate with a low rate of loss of heterozygosity. Oncogene 18: 4044-4046.

Levanon, D., Goldstein, R.E., Bernstein, Y., Tang, H., Goldenberg, D., Stifani, S., Paroush, Z., and Groner, Y. 1998. Transcriptional repression by AML1 and LEF-1 is mediated by the TLE/Groucho corepressors. Proc. Natl. Acad. Sci. 95: 11590-11595.

Leyns, L., Bouwmeester, T., Kim, S.H., Piccolo, S., and De Robertis, E.M. 1997. Frz $\beta 1$ is a secreted antagonist of Wnt signaling expressed in the Spemann organizer. Cell 88: 747756.

Li, L., Yuan, H., Weaver, C.D., Mao, J., Farr, G.H.r., Sussman, D.J., Jonkers, J., Kimelman, D., and Wu, D. 1999a. Axin and Fratl interact with dvl and GSK, bridging Dvl to GSK in Wnt- mediated regulation of LEF-1. EMBO T. 18: 4233-4240.

Li, L., Yuan, H., Xie, W., Mao, J., Caruso, A.M., McMahon, A., Sussman, D.J., and Wu, D. 1999b. Dishevelled proteins lead to two signaling pathways. Regulation of LEF-1 and c-Jun N-terminal kinase in mammalian cells. J. Biol. Chem. 274: 129-134.

Lin, K., Wang, S., Julius, M.A., Kitajewski, J., Moos, Jr., M., and Luyten, F.P. 1997. The cysteine-rich frizzled domain of Frz $\beta-1$ is required and sufficient for modulation of Wnt signaling. Proc. Natl. Acad. Sci. 94: 11196-11200.

McGrew, L.L., Takemaru, K., Bates, R., and Moon, R.T. 1999. Direct regulation of the Xenopus engrailed-2 promoter by the Wnt signaling pathway, and a molecular screen for Wntresponsive genes, confirm a role for Wnt signaling during neural patterning in Xenopus. Mech. Dev. 87: 21-32.

McWhirter, J.R., Neuteboom, S.T., Wancewicz, E.V., Monia, B.P, Downing, J.R., and Murre, C. 1999. Oncogenic homeodomain transcription factor E2A-Pbxl activates a novel WNT gene in pre-B acute lymphoblastoid leukemia. Proc. Natl. Acad. Sci. 96: 11464-11469.

Melkonyan, H.S., Chang, W.C., Shapiro, J.P., Mahadevappa, M., Fitzpatrick, P.A., Kiefer, M.C., Tomei, L.D., and Umansky, S.R. 1997. SARPs: A family of secreted apoptosis-related proteins. Proc. Nat1. Acad. Sci. 94: 13636-13641.

Meneghini, M.D., Ishitani, T., Carter, J.C., Hisamoto, N., Ninomiya-Tsuji, J., Thorpe, C.J., Hamill, D.R., Matsumoto, K., and Bowerman, B. 1999. MAP kinase and Wnt pathways converge to downregulate an HMG-domain repressor in Caenorhabditis elegans. Nature 399: 793-797.

Mirabelli-Primdahl, L., Gryfe, R., Kim, H., Millar, A., Luceri, C., Dale, D., Holowaty, E., Bapat, B., Gallinger, S., and Redston, M. 1999. Beta-catenin mutations are specific for colorectal carcinomas with microsatellite instability but occur in endometrial carcinomas irrespective of mutator pathway. Cancer Res. 59: 3346-3351.

Miyaki, M., Iijima, T., Kimura, J., Yasuno, M., Mori, T., Hayashi, Y., Koike, M., Shitara, N., Iwama, T., and Kuroki, T. 1999. Frequent mutation of beta-catenin and APC genes in primary colorectal tumors from patients with hereditary nonpolyposis colorectal cancer. Cancer Res. 59: 4506-4509.

Miyoshi, Y., Nagase, H., Ando, H., Ichii, S., Nakatsura, S., Aoki, T., Miki, Y., Mori, T., and Nakamura, Y. 1992. Somatic mu- 
tations of the APC gene in colorectal tumors: Mutation cluster region in the APC gene. Hum. Mol. Genet. 1: 229-223.

Miyoshi, Y., Iwao, K., Nagasawa, Y., Aihara, T., Sasaki, Y., Imaoka, S., Murata, M., Shimano, T., and Nakamura, Y. 1998. Activation of the beta-catenin gene in primary hepatocellular carcinomas by somatic alterations involving exon 3. Cancer Res. 58: 2524-2527.

Molenaar, M., van de Wetering, M., Oosterwegel, M., PetersonMaduro, J., Godsave, S., Korinek, V., Roose, J., Destree, O., and Clevers, H. 1996. XTcf-3 transcription factor mediates beta-catenin-induced axis formation in Xenopus embryos. Cell 86: 391-399.

Moriguchi, T., Kawachi, K., Kamakura, S., Masuyama, N., Yamanaka, H., Matsumoto, K., Kikuchi, A., and Nishida, E. 1999. Distinct domains of mouse dishevelled are responsible for the c-Jun $\mathrm{N}$-terminal kinase/stress-activated protein kinase activation and the axis formation in vertebrates. J. Biol. Chem. 274: 30957-30962.

Morin, P.J., Sparks, A.B., Korinek, V., Barker, N., Clevers, H., Vogelstein, B., and Kinzler, K.W. 1997. Activation of betacatenin-Tcf signaling in colon cancer by mutations in betacatenin or APC. Science 275: 1787-1790.

Munemitsu, S., Albert, I., Souza, B., Rubinfeld, B., and Polakis, P. 1995. Regulation of intracellular beta-catenin levels by the adenomatous polyposis coli (APC) tumor-suppressor protein. Proc. Nat1. Acad. Sci. 92: 3046-3050.

Nagase, H., Miyoshi, Y., Horii, A., Aoki, T., Ogawa, M., Utsunomiya, J., Baba, S., Sasazuki, T., and Nakmura, Y. 1992. Correlation between the location of germ-line mutations in the APC gene and the number of colorectal polyps in familial adenomatous polyposis patients. Cancer Res. 52: 40554057.

Nakamura, T., Hamada, F., Ishidate, T., Anai, K., Kawahara, K., Toyoshima, K., and Akiyama, T. 1998a. Axin, an inhibitor of the Wnt signalling pathway, interacts with beta- catenin, GSK-3beta and APC and reduces the beta-catenin level. Genes Cells 3: 395-403.

Ninomiya-Tsuji, J., Kishimoto, K., Hiyama, A., Inoue, J., Cao, Z., and Matsumoto, K. 1999. The kinase TAK1 can activate the NIK-I kappaB as well as the MAP kinase cascade in the IL-1 signalling pathway. Nature 398: 252-256.

Nishida, N., Fukuda, Y., Komeda, T., Kita, R., Sando, T., Furukawa, M., Amenomori, M., Shibagaki, I., Nakao, K., Ikenaga, M., et al. 1994. Amplification and overexpression of the cyclin D1 gene in aggressive human hepatocellular carcinoma. Cancer Res. 54: 3107-3110.

Nishita, M., Hashimoto, M.K., Ogata, S., Laurent, M.N., Ueno, N., Shibuya, H., and Cho, K.W. 2000. Interaction between Wnt and TGF-beta signalling pathways during formation of Spemann's organizer. Nature 403: 781-785.

Noordermeer, J., Klingensmith, J., Perrimon, N., and Nusse, R. 1994. dishevelled and armadillo act in the wingless signalling pathway in Drosophila. Nature 367: 80-82.

Nusse, R. and Varmus, H.E. 1982. Many tumors induced by the mouse mammary tumor virus contain a provirus integrated in the same region of the host genome. Cell 31: 99-109.

Oshima, M., Oshima, H., Kitagawa, K., Kobayashi, M., Itakura, C., and Taketo, M. 1995a. Loss of Apc heterozygosity and abnormal tissue building in nascent intestinal polyps in mice carrying a truncated Apc gene. Proc. Natl. Acad. Sci. 92: 4482-4486.

Oshima, M., Oshima, H., Kobayashi, M., Tsutsumi, M., and Taketo, M.M. 1995b. Evidence against dominant negative mechanisms of intestinal polyp formation by APC gene mutations. Cancer Res. 55: 2719-2722.

Palacios, J. and Gamallo, C. 1998. Mutations in the beta-catenin gene (CTNNB1) in endometrioid ovarian carcinomas. Cancer Res. 58: 1344-1347.

Park, W.S., Oh, R.R., Park, J.Y., Lee, S.H., Shin, M.S., Kim, Y.S., Kim, S.Y., Lee, H.K., Kim, P.K., Oh, S.T., et al. 1999. Frequent somatic mutations of the beta-catenin gene in intestinal-type gastric cancer. Cancer Res. 59: 4257-4260.

Peifer, M. and Polakis, P. 2000. Wnt signaling in oncogenesis and embryogenesis-a look outside the nucleus. Science 287: $1606-1609$

Peng, S.Y., Lai, P.L., and Hsu, H.C. 1993. Amplification of the c-myc gene in human hepatocellular carcinoma: Biologic significance. J. Formos Med. Assoc. 92: 866-870.

Peters, J.M., McKay, R.M., McKay, J.P., and Graff, J.M. 1999. Casein kinase I transduces Wnt signals. Nature 401: 345-350.

Polakis, P. 1999. The oncogenic activation of beta-catenin. Curr. Opin. Genet. Dev. 9: 15-21.

Prieve, M.G. and Waterman, M.L. 1999. Nuclear localization and formation of beta-catenin-lymphoid enhancer factor 1 complexes are not sufficient for activation of gene expression. Mol. Cell. Biol. 19: 4503-4515.

Riese, J., Yu, X., Munnerlyn, A., Eresh, S., Hsu, S.C., Grosschedl, R., and Bienz, M. 1997. LEF-1, a nuclear factor coordinating signaling inputs from wingless and decapentaplegic. Cell 88: 777-787.

Rijsewijk, F., Schuermann, M., Wagenaar, E., Parren, P., Weigel, D., and Nusse, R. 1987. The Drosophila homolog of the mouse mammary oncogene int-1 is identical to the segment polarity gene wingless. Cell 50: 649-657.

Rimm, D.L., Caca, K., Hu, G., Harrison, F.B., and Fearon, E.R. 1999. Frequent nuclear/cytoplasmic localization of betacatenin without exon 3 mutations in malignant melanoma. Am. J. Pathol. 154: 325-329.

Rocheleau, C.E., Downs, W.D., Lin, R., Wittmann, C., Bei, Y., Cha, M., Ali, M., and Mello, C.C. 1997. Wnt signaling and an APC-related gene specify endoderm in early C. elegans embryos. Cell 90: 707-716.

Roelink, H., Wagenaar, E., Lopes da Silva, S., and Nusse, R. 1990. Wnt-3, a gene activated by proviral insertion in mouse mammary tumors, is homologous to int- $1 /$ Wnt- 1 and is normally expressed in mouse embryos and adult brain. Proc. Nat1. Acad. Sci. 87: 4519-4523.

Roose, J. and Clevers, H. 1999. TCF transcription factors: Molecular switches in carcinogenesis. Biochim. Biophys. Acta. 1424: M23-37.

Roose, J., Huls, G., van Beest, M., Moerer, P., van der Horn, K., Goldschmeding, R., Logtenberg, T., and Clevers, H. 1999. Synergy between tumor suppressor APC and the betacatenin-Tcf4 target Tcf1. Science 285: 1923-1926.

Roose, J., Molenaar, M., Peterson, J., Hurenkamp, J., Brantjes, H., Moerer, P., van de Wetering, M., Destree, O., and Clevers, H. 1998. The Xenopus Wnt effector XTcf-3 interacts with Groucho-related transcriptional repressors. Nature 395: 608-612.

Rubinfeld, B., Souza, B., Albert, I., Muller, O., Chamberlain, S.C., Masiarz, F., Munemitsu, S., and Polakis, P. 1993. Association of the APC gene product with $\beta$ catenin. Science 262: $1731-1734$.

Rubinfeld, B., Albert, I., Porfiri, E., Fiol, C., Munemitsu, S., and Polakis, P. 1996. Binding of GSK3 $\beta$ to the APC- $\beta$-catenin complex and regulation of complex assembly. Science 272: 1023-1026.

Rubinfeld, B., Robbins, P., El-Gamil, M., Albert, I., Porfiri, E., and Polakis, P. 1997. Stabilization of beta-catenin by genetic defects in melanoma cell lines. Science 275: 1790-1792.

Sakanaka, C., Weiss, J.B., and Williams, L.T. 1998. Bridging of $\beta$-catenin and glycogen synthase kinase- $3 \beta$ by axin and in- 
hibition of beta-catenin-mediated transcription. Proc. Natl. Acad. Sci. 95: 3020-3023.

Sakanaka, C., Leong, P., Xu, L., Harrison, S.D., and Williams, L.T. 1999. Casein kinase-1 epsilon in the wnt pathway: Regulation of beta-catenin function. Proc. Natl. Acad. Sci. 96: $12548-12552$.

Salic, A., Lee, E., Mayer, L., and Kirschner, M.W. 2000. Control of beta-catenin stability: Reconstitution of the cytoplasmic steps of the wnt pathway in Xenopus egg extracts. Mol. Cell 5: 523-532.

Samowitz, W.S., Powers, M.D., Spirio, L.N., Nollet, F., van Roy, F., and Slattery, M.L. 1999. Beta-catenin mutations are more frequent in small colorectal adenomas than in larger adenomas and invasive carcinomas. Cancer Res. 59: 1442-1444.

Satoh, S., Daigo, Y., Furukawa, Y., Kato, T., Miwa, N., Nishiwaki, T., Kawasoe, T., Ishiguro, H., Fujita, M., Tokino, T., et al. 2000. AXIN1 mutations in hepatocellular carcinomas, and growth suppression in cancer cells by virus-mediated transfer of AXIN1. Nat. Genet. 24: 245-250.

Scott, R.J., Froggatt, N.J., Trembath, R.C., Evans, D.G., Hodgson, S.V., and Maher, E.R. 1996. Familial infiltrative fibromatosis (desmoid tumours) (MIM135290) caused by a recurrent 3' APC gene mutation. Hum. Mol. Genet. 5: 1921-1924.

Seeling, J.M., Miller, J.R., Gil, R., Moon, T., White, T.R., and Virshup, D.M. 1999. Regulation of beta-catenin signaling by the B56 subunit of protein phosphatase 2A. Science 283: 2089-2091.

Seldin, D.C. and Leder, P. 1995. Casein kinase II alpha transgene-induced murine lymphoma: Relation to theileriosis in cattle. Science 267: 894-897.

Sheldahl, L.C., Park, M., Malbon, C.C., and Moon, R.T. 1999. Protein kinase $\mathrm{C}$ is differentially stimulated by Wnt and Frizzled homologs in a G-protein-dependent manner. Curr. Biol. 9: 695-698.

Shih, I.M., Yu, J., He, T.C., Vogelstein, B., and Kinzler, K.W. 2000. The beta-catenin binding domain of adenomatous polyposis coli is sufficient for tumor suppression. Cancer Res. 60: 1671-1676.

Shimizu, H., Julius, M.A., Giarre, M., Zheng, Z., Brown, A.M., and Kitajewski, J. 1997. Transformation by Wnt family proteins correlates with regulation of beta-catenin. Cell Growth Differ. 8: 1349-1358.

Shin, T.H., Yasuda, J., Rocheleau, C.E., Lin, R., Soto, M., Bei, Y., Davis, R.J., and Mello, C.C. 1999. MOM-4, a MAP kinase kinase kinase-related protein, activates WRM-1/LIT-1 kinase to transduce anterior/posterior polarity signals in $C$. elegans. Mol. Cell 4: 275-280.

Shitoh, K., Konishi, F., Iijima, T., Ohdaira, T., Sakai, K., Kanazawa, K., and Miyaki, M. 1999. A novel case of a sporadic desmoid tumour with mutation of the beta catenin gene. $J$. Clin. Pathol. 52: 695-696.

Shtutman, M., Zhurinsky, J., Simcha, I., Albanese, C., D'Amico, M., Pestell, R. and Ben-Ze'ev, A. 1999. The cyclin D1 gene is a target of the beta-catenin/LEF-1 pathway. Proc. Natl. Acad. Sci. 96: 5522-5527.

Smalley, M.J., Sara, E., Paterson, H., Naylor, S., Cook, D., Jayatilake, H., Fryer, L.G., Hutchinson, L., Fry, M.J., and Dale, T.C. 1999. Interaction of axin and Dvl-2 proteins regulates Dvl-2-stimulated TCF-dependent transcription. EMBO J. 18: 2823-2835.

Smits, R., Kielman, M.F., Breukel, C., Zurcher, C., Neufeld, K., Jagmohan-Changur, S., Hofland, N., van Dijk, J., White, R., Edelmann, W., et al. 1999. Apc1638T: A mouse model delineating critical domains of the adenomatous polyposis coli protein involved in tumorigenesis and development. Genes \& Dev. 13: 1309-1321.
Song, D.H., Sussman, D.J., and Seldin, D.C. 2000. Endogenous protein kinase CK2 (casein kinase II) participates in Wnt signaling in mammary epithelial cells. J. Biol. Chem. (in press).

Sparks, A.B., Morin, P.J., Vogelstein, B., and Kinzler, K.W. 1998. Mutational analysis of the APC/beta-catenin/Tcf pathway in colorectal cancer. Cancer Res. 58: 1130-1134.

Su, L.-K., Kinzler, K.W., Vogelstein, B., Presinger, A.C., Moser, A.P., Luongo, P., Gould, K.A., and Dove, W.F. 1992. Multiple intestinal neolasia caused by a mutation in the murine homolog of the APC gene. Science 256: 668-670.

$\mathrm{Su}, \mathrm{L} .-\mathrm{K}$. ., Vogelstein, B., and Kinzler, K.W. 1993. Association of the APC tumor suppressor protein with catenins. Science 262: 1734-1737.

Takemaru, K.I. and Moon, R.T. 2000. The transcriptional coactivator CBP interacts with beta-catenin to activate gene expression. J. Cell. Biol. 149: 249-254.

Tanaka, S., Akiyoshi, T., Mori, M., Wands, J.R., and Sugimachi, K. 1998. A novel frizzled gene identified in human esophageal carcinoma mediates APC/beta-catenin signals. Proc. Nat1. Acad. Sci. 95: 10164-10169.

Tejpar, S., Nollet, F., Li, C., Wunder, J.S., Michils, G., dal Cin, P., Van Cutsem, E., Bapat, B., van Roy, F., Cassiman, J.J., et al. 1999. Predominance of beta-catenin mutations and betacatenin dysregulation in sporadic aggressive fibromatosis (desmoid tumor). Oncogene 18: 6615-6620.

Tetsu, O. and McCormick, F. 1999. Beta-catenin regulates expression of cyclin D1 in colon carcinoma cells. Nature 398: 422-426.

Thomas, G.M., Frame, S., Goedert, M., Nathke, I., Polakis, P., and Cohen, P. 1999. A GSK3-binding peptide from FRAT1 selectively inhibits the GSK3-catalysed phosphorylation of axin and beta-catenin. FEBS Lett. 458: 247-251.

Umeda, T., Yamamoto, T., Kajino, K., and Hino, O. 2000. betacatenin mutations are absent in hepatocellular carcinomas of SV40 T-antigen transgenic mice. Int. J. Oncol. 16: 11331136.

Uren, A., Reichsman, F., Anest, V., Taylor, W.G., Muraiso, K., Bottaro, D.P., Cumberledge, S., and Rubin, J.S. 2000. Secreted frizzled-related protein-1 binds directly to Wingless and is a biphasic modulator of Wnt signaling. J. Biol. Chem. 275: 4374-4382.

van de Wetering, M., Cavallo, R., Dooijes, D., van Beest, M., van Es, J., Loureiro, J., Ypma, A., Hursh, D., et al. 1997. Armadillo coactivates transcription driven by the product of the Drosophila segment polarity gene dTCF. Cell 88: 789-799.

van der Luijt, R.B., Meera Khan, P., Vasen, H.F., Breukel, C., Tops, C.M., Scott, R.J., and Fodde, R. 1996. Germline mutations in the 3' part of APC exon 15 do not result in truncated proteins and are associated with attenuated adenomatous polyposis coli. Hum. Genet. 98: 727-734.

van Genderen, C., Okamura, R.M., Farinas, I., Quo, R.G., Parslow, T.G., Bruhn, L., and Grosschedl, R. 1994. Development of several organs that require inductive epithelial-mesenchymal interactions is impaired in LEF-1-deficient mice. Genes \& Dev. 8: 2691-2703.

Van Nhieu, J.T., Renard, C.A., Wei, Y., Cherqui, D., Zafrani, E.S., and Buendia, M.A. 1999. Nuclear accumulation of mutated beta-catenin in hepatocellular carcinoma is associated with increased cell proliferation. Am. J. Pathol. 155: 703-710.

Vleminckx, K., Wong, E., Guger, K., Rubinfeld, B., Polakis, P., and Gumbiner, B. 1997. Adenomatous polyposis coli tumor suppressor protein has signaling acitivity in Xenopus laevis embryos resulting in the induction of an ectopic dorsoanterior axis. J. Cell Biol. 136: 411-420.

Voeller H.J., Truica, C.I., and Gelmann, E.P. 1998. Beta-catenin mutations in human prostate cancer. Cancer Res. 58: 2520- 
2523.

Walon, C., Kartheuser, A., Michils, G., Smaers, M., Lannoy, N., Ngounou, P., Mertens, G., and Verellen-Dumoulin, C. 1997. Novel germline mutations in the APC gene and their phenotypic spectrum in familial adenomatous polyposis kindreds. Hum. Genet. 100: 601-605.

Waltzer, L. and Bienz, M. 1998. Drosophila CBP represses the transcription factor TCF to antagonize Wingless signalling. Nature 395: 521-525.

Wang, S., Krinks, M., Lin, K., Luyten, F.P., and Moos, M., Jr. 1997. Frzb, a secreted protein expressed in the Spemann organizer, binds and inhibits Wnt-8. Cell 88: 757-766.

Wang, S.S., Esplin, E.D., Li, J.L., Huang, L., Gazdar, A., Minna, J., and Evans, G.A. 1998. Alterations of the PPP2R1B gene in human lung and colon cancer. Science 282: 284-287.

Wei, Y., Fabre, M., Branchereau, S., Gauthier, F., Perilongo, G., and Buendia, M.A. 2000. Activation of beta-catenin in epithelial and mesenchymal hepatoblastomas. Oncogene 19: 498-504.

Willert, K., Brink, M., Wodarz, A., Varmus, H., and Nusse, R. 1997. Casein kinase 2 associates with and phosphorylates dishevelled. EMBO J. 16: 3089-3096.

Willert, K., Logan, C.Y., Arora, A., Fish, M., and Nusse, R. 1999a. A Drosophila Axin homolog, Daxin, inhibits Wnt signaling. Development 126: 4165-4173.

Willert, K., Shibamoto, S., and Nusse, R. 1999b. Wnt-induced dephosphorylation of axin releases beta-catenin from the axin complex. Genes \& Dev. 13: 1768-1773.

Wodarz, A. and Nusse, R. 1998. Mechanisms of Wnt signaling in development. Annu. Rev. Cell. Dev. Biol. 14: 59-88.

Wong, G.T., Gavin, B.J., and McMahon, A.P. 1994. Differential transformation of mammary epithelial cells by Wnt genes. Mol. Cell. Biol. 14: 6278-6286.

Wright, K., Wilson, P., Morland, S., Campbell, I., Walsh, M., Hurst, T., Ward, B., Cummings, M., and Chenevix-Trench, G. 1999. beta-catenin mutation and expression analysis in ovarian cancer: Exon 3 mutations and nuclear translocation in 16\% of endometrioid tumours. Int. J. Cancer 82: 625-629.

Wu, J.S., Paul, P., McGannon, E.A., and Church, J.M. 1998. APC genotype, polyp number, and surgical options in familial adenomatous polyposis. Ann. Surg. 227: 57-62.

Xu, L., Corcoran, R.B., Welsh, J.W., Pennica, D., and Levine, A.J. 2000. WISP-1 is a Wnt-1- and beta-catenin-responsive oncogene. Genes \& Dev. 14: 585-595.

Yamaguchi, K., Shirakabe, K., Shibuya, H., Irie, K., Oishi, I., Ueno, N., Taniguchi, T., Nishida, E., and Matsumoto, K. 1995. Identification of a member of the MAPKKK family as a potential mediator of TGF-beta signal transduction. Science 270: 2008-2011.

Yamamoto, H., Kishida, S., Kishida, M., Ikeda, S., Takada, S., and Kikuchi, A. 1999. Phosphorylation of axin, a Wnt signal negative regulator, by glycogen synthase kinase- $3 \beta$ regulates its stability. J. Biol. Chem. 274: 10681-10684.

Yang-Snyder, J., Miller, J.R., Brown, J.D., Lai, C.J., and Moon, R.T. 1996. A frizzled homolog functions in a vertebrate Wnt signaling pathway. Curr. Biol. 6: 1302-1306.

Yost, C., Torres, M., Miller, J.R., Huang, E., Kimelman, D., and Moon, R.T. 1996. The axis-inducing activity, stability, and subcellular distribution of beta-catenin is regulated in Xenopus embryos by glycogen synthase kinase 3. Genes \& Dev. 10: 1443-1454.

Yost, C., Farr, G.H., 3rd, Pierce, S.B., Ferkey, D.M., Chen, M.M., and Kimelman, D. 1998. GBP, an inhibitor of GSK-3, is implicated in Xenopus development and oncogenesis. Cell 93: 1031-1041.

Zeng, L., Fagotto, F., Zhang, T., Hsu, W., Vasicek, T.J., Perry,
W.L., Lee, J.J., Tilghman, S.M., Gumbiner, B.M., and Constantini, F. 1997. The mouse Fused locus encodes Axin, an inhibitor of the Wnt signaling pathway that regulates embryonic axis formation. Cell 90: 181-192.

Zorn, A.M., Barish, G.D., Williams, B.O., Lavender, P., Klymkowsky, M.W., and Varmus, H.E. 1999. Regulation of Wnt signaling by Sox proteins: XSox17 alpha/beta and XSox3 physically interact with beta-catenin. Mol. Cell 4: 487-498.

Zurawel, R.H., Chiappa, S.A., Allen, C., and Raffel, C. 1998. Sporadic medulloblastomas contain oncogenic beta-catenin mutations. Cancer Res. 58: 896-899. 


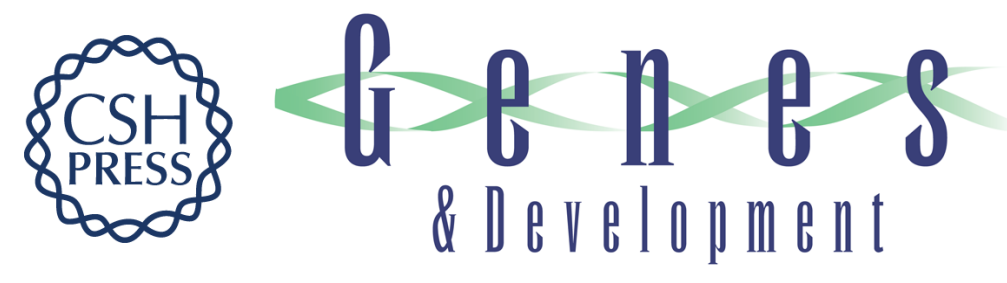

\section{Wnt signaling and cancer}

Paul Polakis

Genes Dev. 2000, 14:

Access the most recent version at doi:10.1101/gad.14.15.1837

References This article cites 175 articles, 95 of which can be accessed free at: http://genesdev.cshlp.org/content/14/15/1837.full.html\#ref-list-1

License

Email Alerting Receive free email alerts when new articles cite this article - sign up in the box at the top Service right corner of the article or click here.

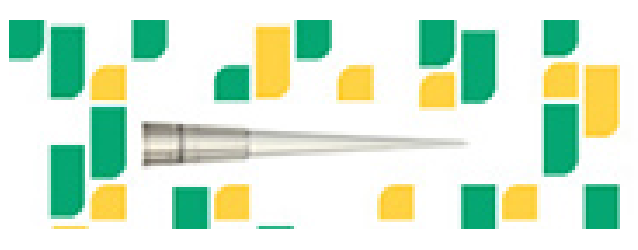

Focused on your science. 